\title{
Ex Post Modernism: How the First Amendment Framed Nonrepresentational Art
}

\author{
Sonya G. Bonneau*
}

TABLE OF CONTENTS

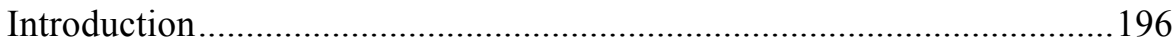

I. The Cultural Alliances of Modernism and Free Speech.......................200

A. The Politics of Modernism.....................................................201

B. The Apolitical Art of American Democracy............................205

II. Postmodern Ideas, Messages, and Politics ...........................................2 210

III. Modernism in the Court: A Breakdown.............................................2.215

A. The Artistic Expression Category: Politics to Formalism ........216

B. Jackson Pollock's Painting as Speech, 1995 ............................218

C. Ex Post Hurley: Disorder in the Marketplace ...........................221

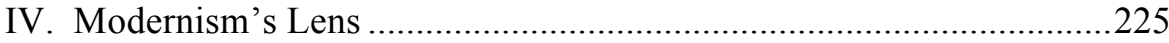

A. Theory: Apolitical Things and Autonomy ……......................226

B. Context: The Museum Confines ............................................227

C. Update: What Modernism Doesn't See.....................................2229

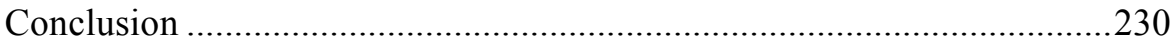

* Professor, Legal Research and Writing, Georgetown University Law Center. I would like to thank David Wolitz, Jeffrey Shulman, Josh Teitelbaum, and Susan McMahon for their feedback on earlier drafts, as well as Rebecca Tushnet for her invaluable critique and suggestions. I also thank the Georgetown University Law Center for its support. 


\section{INTRODUCTION}

In Hurley v. Irish-American Gay, Lesbian \& Bisexual Group of Boston, the Supreme Court asserted that Jackson Pollock's paintings are "unquestionably shielded" under the First Amendment. ${ }^{1}$ Previously, visual art's main doctrinal residence stood in obscenity law's backyard, as a vague definitional tautology: art constitutes speech so long as it is not obscene, ${ }^{2}$ and speech is not obscene if it is art. $^{3}$ The Hurley Court offered no elaboration as to the "drip" painting's constitutional relevance, ${ }^{4}$ but, even as mere illustrative dictum, the declaration received independent attention on two levels. First, the remark reified a longstanding assumption that visual art was "speech," offering a specific example outside the realm of obscenity law. ${ }^{5}$ Second, the reference to Jackson Pollock's painting did not merely confer robust protection to art, but definitively extended its embrace to apolitical, nonlinguistic imagery. ${ }^{6}$

1. 515 U.S. 557, 569 (1995) (remarking that if a "particularized message" was required for constitutional protection, the First Amendment "would never reach the unquestionably shielded painting of Jackson Pollock, music of Arnold Schöenberg, or Jabberwocky verse of Lewis Carroll"). This Article focuses on visual art. Because Jabberwocky involves words, it possesses a more direct route to speech status than purely visual expression. Instrumental music may be closer categorically, but is likewise beyond the scope of this Article. For a discussion of instrumental music as speech, see Alan K. Chen, Instrumental Music and the First Amendment, 66 HASTINGS L.J. 381 (2015). This Article refers to First Amendment law only in relation to the free speech clause. See U.S. CONST. amend. I ("Congress shall make no law ... abridging the freedom of speech, or of the press ....”). It focuses on what constitutes First Amendment speech, rather than whether a given instance of speech is protected under particular circumstances. See Frederick Schauer, The Boundaries of the First Amendment: A Preliminary Exploration of Constitutional Salience, 117 HARV. L. REV. 1765, 1769-71 (2004) (distinguishing between coverage - whether the First Amendment "shows up" in the first instance - and protection).

2. Kaplan v. California, 413 U.S. 115, 119-20 (1973) ("As with pictures, films, paintings, drawings, and engravings, both oral utterance and the printed word have First Amendment protection until they collide with the long-settled position of this Court that obscenity is not protected by the Constitution.").

3. See Miller v. California, 413 U.S. 15, 24 (1973) (work can be considered obscene only if it lacks "serious literary, artistic, political, or scientific value"); see also Mark Tushnet, Art and the First Amendment, 35 COLUM. J.L. \& ARTS 169, 208 (2012) ("Throughout its efforts to define obscenity, the Court has simply assumed that material that can be described as sufficiently artistic cannot be obscene.").

4. The Court does not specify any particular painting or that it is referring to Pollock's nonrepresentational work, but there is no reason to question this inference.

5. See Edward J. Eberle, Art as Speech, 11 U. PA. J.L. \& Soc. Change 1, 1 (2008) (citing Hurley among cases demonstrating "wide agreement that art speech is protected speech"); Sheldon Nahmod, Artistic Expression and Aesthetic Theory: The Beautiful, the Sublime and The First Amendment, 1987 WIS. L. REV. 221, 242 (1987) (noting the absence of discussion about the place of artistic expression in the marketplace of ideas, despite "the unquestioned assumption that somehow it belongs there").

6. See Genevieve Blake, Expressive Merchandise and the First Amendment in Public Fora, 34 FORDHAM URB. L.J. 1049, 1058 (2007) (quoting the Hurley holding as signifying "a clear, indeed 'unquestionable' protection for apolitical artworks"); David Greene, Why Protect Political Art as "Political Speech"?, 27 HASTINGS COMM. \& ENT. L.J. 359, 364 (2005) (suggesting increasingly expanding embrace of artistic expression such that, "by 1995, the Court had realized the 'unquestionable' First Amendment protection due even abstract works"); Paul E. Salamanca, Video Games As A Protected Form of Expression, 40 GA. L. REV. 153, 164 (2005) (describing Hurley as an embrace of "even pure art"); James Weinstein, Participatory Democracy as the Central Value of 
No one questions that conclusion. As Mark Tushnet has aptly observed, it is correct by "clearly widespread intuition."7 But, as Tushnet has also explained, the result for legal reasoning is highly conflicted. ${ }^{8}$ And, from the vantage of traditional First Amendment principles, no one can agree on why the conclusion is correct. ${ }^{9}$ To the extent that speech, fundamentally, requires communication, how can it encompass expression devoid of words, discernable message, or shared meaning? ${ }^{10}$

The three most commonly-cited purposes in explaining the scope of the free speech clause include: (1) protecting a robust marketplace of ideas in the ongoing quest for truth; ${ }^{11}$ (2) enabling informed participation in a democracy; ${ }^{12}$ and (3) ensuring the liberty of self-realization or individual autonomy. ${ }^{13}$ But if ideasespecially political ideas - are the crown jewels of speech serving any of these objectives, ${ }^{14}$ why does art deemed "noncognitive" 15 and apolitical share this

American Free Speech Doctrine, 97 VA. L. REV. 491, 499 (2011) (observing that "rigorous protection has been extended across the board even to art that has no political purpose").

7. See Tushnet, supra note 3, at 197.

8. These anomalies are the subject of Tushnet's comprehensive discussion of art and First Amendment jurisprudence. See generally Tushnet, supra note 3.

9. A definitive First Amendment theory has never been settled for the larger category of nonpolitical visual art. See Schauer, supra note 1, at 1784-87 (listing art among "outcomes in search of a theory").

10. See Tushnet, supra note 3, at 194 ("It is entirely unclear whether anyone imputes any meaning to [Blue Poles, No. 11], much less a political meaning, and whatever meanings are imputed are unlikely to be shared widely enough to make the painting a word equivalent.").

11. See Red Lion Broad. Co. v. F.C.C., 395 U.S. 367, 390 (1969) ("It is the purpose of the First Amendment to preserve an uninhibited marketplace of ideas in which truth will ultimately prevail, rather than to countenance monopolization of that market, whether it be by the Government itself or a private licensee.”); Abrams v. United States, 250 U.S. 616, 630 (1919) (Holmes, J., dissenting) (“[T]he best test of truth is the power of the thought to get itself accepted in the competition of the market . . .."); see also C. Edwin Baker, The First Amendment and Commercial Speech, 84 IND. L.J. 981,982 (2009) (noting that beginning in the 1970s, "virtually all First Amendment scholarship and the dominant doctrinal formulations accepted some version of a marketplace of ideas theory"); Stuart Minor Benjamin, Algorithms and Speech, 161 U. PA. L. REV. 1445, 1455 (2013) (referring to the marketplace of ideas rationale as the "most commonly invoked by the Supreme Court"); Thomas I. Emerson, Toward a General Theory of The First Amendment, 72 YALE L.J. 877, 881 (1963) (describing traditional view of free expression as "the best process for advancing knowledge and discovering truth").

12. See Robert Post, Participatory Democracy and Free Speech, 97 VA. L. REV. 477, 483 (2011) (defining "speech" as "speech acts and media of communication that are socially regarded as necessary and proper means of participating in the formation of public opinion").

13. E.g., C. Edwin Baker, Scope of the First Amendment Freedom of Speech, 25 UCLA L. REV. 964, 966 (1978) (arguing that "speech is protected not as a means to a collective good but because of the value of speech conduct to the individual"); Emerson, supra note 11, at 879 ("The right to freedom of expression is justified first of all as the right of an individual purely in his capacity as an individual."); Martin H. Redish, The Value of Free Speech, 130 U. PA. L. REV. 591, 593 (1982) ("[T]he constitutional guarantee of free speech ultimately serves only one true value, which I have labeled 'individual selfrealization."').

14. E.g., Citizens United v. FEC, 558 U.S. 310, 329 (2010) (referring to political speech as "central to the meaning and purpose of the First Amendment"); Morse v. Frederick, 551 U.S. 393, 403 (2007) ("Political speech, of course, is "at the core of what the First Amendment is designed to protect." (quoting Virginia v. Black, 538 U.S. 343, 365 (2003))); Roth v. United States, 354 U.S. 476, 484 (1957) ("The protection given speech and press was fashioned to assure unfettered interchange of ideas for the bringing about of political and social changes desired by the people.”).

15. See, e.g., Randall P. Bezanson, Art and the Constitution, 93 IowA L. REV. 1593, 1598 (2008) 
constitutional eminence? The only well-theorized purpose that readily accommodates protecting nonrepresentational art as speech is self-realization as an end unto itself (rather than in service of the other two goals), ${ }^{16}$ a purpose that, Lee Bollinger observes, "has never achieved the widely accepted status in First Amendment jurisprudence of the other two."17 In this light, the Hurley Court's certainty about the First Amendment stature of Jackson Pollock's painting is striking, and no less the unanimity among legal scholars that nonrepresentational art stands among the "core cases of protected expression."18

This Article is not aimed at resolving that jurisprudential debate. Rather, this Article argues that its framework is both a cause and symptom of First Amendment law's disconnect from contemporary artistic expression. Specifically, the Supreme Court's conclusion in Hurley and its overwhelming approval are informed and framed by a particular art historical moment-one that no longer reflects the art world. This outdated cultural lens restricts, rather than expands, how artistic expression is conceptualized as speech. To place First Amendment law on solid footing with visual artistic expression, the law needs to open its eyes to the changes that have occurred over the past half-century.

My approach relies on art historical sources to help break through the discursive paralysis generated by a subject that law is loath to address, ${ }^{19}$ yet, by exultant

("Art, as I use the term here, is a representation perceived not mainly through our cognitive faculties, but instead through our senses unconstrained by reason."); Nahmod, supra note 5, at 241 (describing nonrepresentational art as a type of "noncognitive" communication); Melvin B. Nimmer, The Meaning of Symbolic Speech Under the First Amendment, 21 UCLA L. REV. 29, 35 (1973) (referring to nonrepresentational art as "substantially devoid of all cognitive content"); Kevin Saunders, Media Violence and the Obscenity Exception to the First Amendment, 3 WM. \& MARY BILL RTS. J. 107, 165 (1994) (describing nonrepresentational art as communicating noncognitive, "emotive messages"). Although I find the term "noncognitive" misplaced, I use it consistent with the conventions of legal commentary as meaning lacking a propositional idea.

16. See C. Edwin Baker, Autonomy and Free Speech, 27 Const. Comment. 251, 271 (2011) (explaining First Amendment coverage of abstract art as a matter of the expressive liberty of artists and audiences); Baker, supra note 13.

17. Lee C. Bollinger \& Geoffrey R. Stone, Dialogue, in Eternally Vigilant: Free SPEECH IN THE MODERN ERA 1, 23 (Lee C. Bollinger \& Geoffrey R. Stone eds., 2002) ("It is well accepted among the justices and legal scholars today that the fundamental purpose of free speech is to maximize the search for truth and to protect the democratic decisionmaking process."); see also Brandt v. Bd. of Educ. of Chi., 480 F.3d 460, 465 (7th Cir. 2007) ("Self-expression is not to be equated to the expression of ideas or opinions and thus to participation in the intellectual marketplace."); ROBERT C. POST, DEMOCRACY, EXPERTISE, AND ACADEMIC FREEDOM 23 (2012) (arguing that the law must distinguish between situations where a person should have autonomy and those where the person is dependent); Jed Rubenfeld, The Freedom of Imagination: Copyright's Constitutionality, 112 YALE L.J. 1, 4 (2002) (claiming that protecting art on the basis of individual self-realization frames art "too narcissistically"); Frederick Schauer, Must Speech Be Special?, 78 Nw. U. L. REv. 1284, 1289-93 (1983) (canvassing reasons why autonomy-based theories are not distinguishable from general principles of personal liberty, and thus insufficient to explain the constitutional distinction afforded "speech").

18. See Steven L. Winter, Re-Embodying Law, 58 Mercer L. Rev. 869, 893 (2007) (declaring that "all would agree" that nonrepresentational art is speech, "even if no one can say exactly what the message might be").

19. Judging art was famously deemed off-limits in early twentieth century law. See Bleistein v. Donaldson Lithographing Co., 188 U.S. 239, 251 (1903) (Holmes, J.) ("It would be a dangerous undertaking for persons trained only to the law to constitute themselves final judges of the worth of 
refrain, "goes without saying." 20 I do not suggest that law should take art history into account when analyzing nonrepresentational art. Rather, it already has. Nonrepresentational art in contemporary First Amendment discourse reflects the legacy of a deeply symbolic cultural construct forged in twentieth-century modernism. The reference to Jackson Pollock's painting in Hurley is its anemic residue.

While Mark Tushnet has probed the analytical complexities of including Pollock's painting within the scope of the free speech clause, he, like other scholars, reasons backwards from the historical outcome of American modernism. The art historical lens established by the modernist era, however, is not a reliable means of contemplating the First Amendment's relationship to artistic expression today. Postmodernism (loosely defined) ${ }^{21}$ challenged modernism's normative architecture and strategically engaged previously segregated forms of culture, like advertising, politics, and entertainment media. It used concept to break through the fortress of pure visuality. It tore down the romantic ideal of individual authorship by celebrating mass production and appropriation.

Postmodernism's conceptual orientation and dissolution of boundaries might First Amendment law's broadly inclusive marketplace of ideas, but instead art and law speak past one another. The result of Jackson Pollock as the exemplar of constitutionally covered visual art is not simply a matter of over- or underinclusion, but a doctrine and discourse that is reductive, anachronistic, and culturally alienated. ${ }^{22}$

In Part I, I provide background illustrating the cultural entanglement of freedom of expression with the vanguard art movement Abstract Expressionism, whose ascent to mainstream success occurred in tandem with the rise of U.S. political and economic strength in the years following World War II. In Part II, I briefly describe the postmodern insurgency against the dictates of high modernism, especially the latter's apparent isolation from social concerns and thrall to the individual genius paradigm. In Part III, I examine the migration of modernist

pictorial illustrations, outside of the narrowest and most obvious limits."). This nexus of aesthetic judgment and judicial reasoning has been probed in legal literature. See, e.g., Christine Haight Farley, Judging Art, 79 TUL. L. REV. 805, 811-13 (2005) (arguing that despite proclaimed reluctance to engage in aesthetic judgments based on inherent subjectivity, judges do so implicitly); Richard A. Posner, Art for Law's Sake, 58 AM. SchOLAR 513, 514 (1989) ("[W]hile it is possible to make objective measurements of physical properties such as weight and speed, it is not possible to make such measurements of artistic value, because people having different values and preferences do not agree and cannot be brought to agree on how to determine the presence of that attribute and even how to define it.”); Alfred C. Yen, Copyright Opinions and Aesthetic Theory, 71 S. CAL. L. REV. 247 (1998) (arguing that judicial opinions on copyright law contain implicit views on aesthetic theory).

20. Nat'l Endowment for the Arts v. Finley, 524 U.S. 569, 602 (1998) (Souter, J., dissenting) ("It goes without saying that artistic expression lies within this First Amendment protection.").

21. This Article makes no claim to definitively characterizing postmodernism and uses the term primarily as a means of referencing artistic developments historically situated after modernism, in relation to the themes and theories discussed.

22. Although this Article doesn't delve into the intersection of free speech with the fair use doctrine, several points made here about law's dissonance with postmodern art are manifest in copyright cases involving appropriation art, a subject incisively examined in Amy Adler, Fair Use and the Future of Art, 91(3) N.Y.U. L. REV. (forthcoming 2016). 
culture into First Amendment case law, leading up to the Supreme Court's embrace of Jackson Pollock's painting as speech in Hurley, followed by its dissonant legacy in contemporary jurisprudence. In Part IV, I demonstrate the ways in which contemporary legal discourse involving nonrepresentational art remains circumscribed by the art historical vision of modernism, perpetuating law's acute misalignment with postmodern art and culture.

Rather than advancing another normative theory aimed at justifying nonrepresentational art as speech, this Article argues that modernism raised the question, and paralyzed the inquiry. Closing the culture gap requires seeing the law's invisible art museum and its implicit interpretive construct. These walls should be razed, opening up the discursive field to facilitate a more meaningful integration of art with contemporary First Amendment jurisprudence.

\section{THE CULTURAL ALLIANCES OF MODERNISM AND FREE SPEECH}

The First Amendment is not only law, but a national identity. ${ }^{23}$ Despite its pervasive cultural presence, ${ }^{24}$ the law distinguishes between constitutionallyprotectable speech and regular speech. ${ }^{25}$ That is, not all spoken or written expression triggers a First Amendment analysis (language susceptible to government regulation occurs, for example, in the context of contract, fraud, conspiracy, and copyright law). Frederick Schauer proposes that speech boundaries are best explained descriptively, rather than by normative theory, through the particular social and historical conditions of the First Amendment's development. ${ }^{26}$ In Schauer's view, the distinction between covered and uncovered speech "is a function of largely nondoctrinal forces." 7 Not unrelatedly, constitutional law scholars have observed that contemporary free speech discourse is a product of the twentieth century, during which time speech jurisprudence became increasingly protective. ${ }^{28}$

This section provides a descriptive account of Abstract Expressionism, the preeminent artistic outpost of modernism in post-World War II America. ${ }^{29}$ I offer

23. See, e.g., SteVen H. Shiffrin, The First AmEndment, Democracy, AND Romance 5 (1990) (“America has had a romance with the first amendment.").

24. Id. at 87 (observing that "the first amendment plays a role in American culture that ranges beyond its legal bounds").

25. See POST, supra note 17, at 15 (referring to "vast stretches of ordinary verbal expression" that are excluded from "speech" for First Amendment purposes); Schauer, supra note 1, at 1777 (observing that it would be a mistake to assume that all speech beyond the defined exclusions is covered by the First Amendment). This Article uses the word "speech" to denote First Amendment speech, unless otherwise specified.

26. Schauer, supra note 1, at 1787 (arguing that speech boundaries are best revealed in the "political, sociological, cultural, historical, psychological, and economic milieu in which the First Amendment exists and out of which it has developed").

27. Schauer, supra note 1 , at 1788.

28. See Bollinger \& Stone, supra note 17, at 1 (observing that the contemporary First Amendment "is an invention of the twentieth century").

29. DAVID ANFAM, ABSTRACT EXPRESSIONISM 7 (1990) (describing Abstract Expressionism as "a landmark in the general history of art and of modern art in particular"). I refer to "Abstract Expressionism" in relation to the artists and abstract work most associated with this name in post-World 
it as backstory to the widespread assumption - a foregone conclusion in Hurleythat nonrepresentational art belongs within the scope of the free speech clause. The notoriously indecipherable, apolitical, and nonrepresentational work of the Abstract Expressionists acquired a unique First Amendment salience in the 1950s, in culture rather than in legal doctrine. ${ }^{30}$ This symbolic alliance was fortified by particular historical, social, and political conditions, yet, as will be explained, preconditioned on the irrelevance of these same influences.

I divide this selective overview of Abstract Expressionism into two parts, broadly reflecting relevant shifts in associated public perceptions and rhetoric. ${ }^{31}$

\section{A. The Politics of Modernism}

In the early twentieth century, modern art-in the form of abstraction-was European. America's art historical tradition was seeded and cultivated in realism, a style reflecting this country's Puritan roots and, art historians have suggested, a defiance of societal perceptions that art was an "unmanly," dishonest, and fanciful pursuit. ${ }^{32}$ In the 1930 s, realist art was both explicitly and implicitly influenced by political and economic conditions, and often avowedly nationalistic, as under New Deal art programs like the Federal Art Project. ${ }^{33}$ Thomas Hart Benton's regionalist paintings and murals, for example, captured this liberal-democratic spirit through an idealized iconography of social reform and American progress. ${ }^{34}$ Even less idealized paintings of labor by American social realists, like Ben Shahn, were consistent with the idea of a distinctly American art predicated on literal representation - accessibility was itself a democratic principle. ${ }^{35}$

First generation Abstract Expressionists, including Jackson Pollock and Willem de Kooning, became acquainted through New Deal art programs in the 1930s,

War II America, especially Jackson Pollock and Willem de Kooning. Abstract Expressionism was not actually a movement, in the sense of a shared intent or mission, but the degree of unanimity among the artists does not significantly impact the thesis of this Article.

30. See generally Ann Gibson, Abstract Expressionism's Evasion of Language, 47 ART J. 208 (1988) (discussing major art historical theories explaining the Abstract Expressionists' defiance of verbal translation).

31. This organization should not be construed as linear in a temporal sense; conflicting theories and interpretations intersected at all stages.

32. IrVing SANDler, The Triumph of American Painting 7 (1970) ("In a society whose business was business, artistic creation was suspect as an unmanly and frivolous evasion of reality."); Leo Steinberg, Other Criteria, in Other Criteria: Confrontations with Twentieth-Century ART 55, 56-58 (1972) (discussing realist Thomas Eakins as the quintessential "American artist" because he attempted to assimilate the role of the painter with the Puritan work ethic: devoid of sentiment, efficient, and honest).

33. See Paul Wood et Al., Modernism in Dispute: Art since the Forties 12-16 (1993) (detailing political activism of artists in the 1930s and social agenda of Federal Art Project).

34. Benton's narrative-based depictions of American life, along with his preference for publiclyaccessible murals, were tied to political and social reform, including disavowal of New York's elitist art world. See Erika Doss, The Art of Cultural Politics: From Regionalism to Abstract Expressionism, in ReCasting America: Culture and Politics in the Age OF Cold War 195, 200 (Lary May ed., 1989).

35. See Jane de Hart Mathews, Art and Politics in Cold War America, 81 Am. HIst. Rev. 762, 782 (1976). 
working in a generally realistic style. ${ }^{36}$ These New York-based artists looked to new sources in the 1940s, including European abstraction and surrealism, ${ }^{37}$ becoming an avant-garde art movement (also referred to as the "New York School"), whose ascent dramatically steepened in the years following World War II.

Clement Greenberg, the art critic credited with the greatest influence in shaping the cultural reception and legacy of Abstract Expressionism, is renowned for his post-war aesthetic theory of formalism. Formalist artistic critique, broadly stated, assesses the art object as autonomous and self-justifying by its surface qualities of form and color. But Greenberg originally developed formalist art theory in conjunction with specific social and political concerns. In Avant-Garde and Kitsch, from 1939, he explained mass culture ("kitsch") as the inexpensive means by which "totalitarian regimes seek to ingratiate themselves with their subjects," which avant-garde painters could refute by divesting representation from the picture plane. ${ }^{38}$ The artist's "search of the "absolute," 39 inherently rejecting bourgeois society and capitalism, would clear the path to social revolution by preserving genuine culture, which unlike kitsch, resisted exploitation. ${ }^{40}$

Abstract art was not rejected by fascists and Stalinists as too critical of government, Greenberg claimed, but rather, unlike mass culture, "too innocent . . . too difficult to inject effective propaganda into . . .."41 Greenberg continued to fine-tune his theory, offering an art historical trajectory toward abstraction that began after Romanticism, when "the avant-garde saw the necessity of an escape from ideas, which were infecting the arts with the ideological struggles of society." 42 Manet, for example, was transformative in this move away from representational content to a more socially impenetrable focus on the material essence of painting: acknowledgment of the flat picture plane. ${ }^{43}$

Post-war society, however, complicated Greenberg's revolutionary social lens, and the socialist leanings of other New York intellectuals. Indeed, the deeply subjective, inward turn of Abstract Expressionist painting paralleled a systemic

36. Pollock trained under Thomas Hart Benton in the 1930s.

37. One key channel was New York's Museum of Modern Art. See Susan Noyes Platt, Modernism, Formalism, and Politics: The "Cubism and Abstract Art" Exhibition of 1936 at the Museum of Modern Art, 47 ART J. 284 (1988). Moreover, by the mid-1940s, émigrés from Europe had entered the New York art world, including French surrealists (Yves Tanguy, Andre Masson, Andre Breton), abstract artists Josef Albers and Hans Hofmann from Germany, and Dutch artist Piet Mondrian. See de Hart Mathews, supra note 35, at 773-74 (noting that the émigré community in New York included the leaders of nearly every twentieth-century non-realistic art movement).

38. Clement Greenberg, AVANT-GARDE AND Kitsch (1939), reprinted in Clement Greenberg, ArT AND Culture: Critical Essays 3, 19 (1961).

39. Id. at 5 .

40. See id. at 10-12, 19 (discussing mass culture in connection with urbanization, industrialization, and commodification of "genuine culture"); see also T.J. Clark, In Defense of Abstract Expressionism, OCTOBER 22, 41 (Summer 1994) (contrasting Greenberg's early "Trotskyite" use of the term kitsch, having class connotations, with mid-1950s formalist concerns).

41. GREENBERG, supra note 38, at 19.

42. Clement Greenberg, Towards a Newer Laocoon, 7 PARTISAN ReV. 296, 301 (1940).

43. Id. at 302,308 . 
disillusionment with and withdrawal from socio-economic theories of society toward individualism and psychological motives. ${ }^{44}$ As the Romantic author paradigm of individual genius flourished, ${ }^{45}$ the painters' work increasingly resisted verbal interpretation. ${ }^{46}$ And as conventional iconographic systems of communication receded from the picture plane and became entirely unintelligible, extrinsic theories of meaning proliferated, colored by post-war themes of the individual unconscious, Jungian psychology, antirationalism, and the primitive. ${ }^{47}$

Although the growing censorial impulse toward art in general may have initially targeted the "un-American" messages of certain realist works, abstract art was not immune from political interpretation. ${ }^{48}$ In the incipient climate of fear leading into McCarthyism, Michigan Congressman George Dondero became the dominant voice of communist accusations in art. ${ }^{49}$ Although he did not hesitate to decry the apparent communist messages in naturalistic art, ${ }^{50}$ he directed his sharpest vitriol at European abstraction or "modern art." communist infiltration, Dondero highlighted nonrepresentational art's foreign roots, its apparent pictorial disorder, and its elitist disavowal of public comprehension to press one message: abstract form was inherently threatening to American values

44. See Michael LeJa, ReFraming ABSTRACT EXPRESSIONISM: SubJeCtivity and Painting IN THE 1940s 194-202 (1993) (discussing psychological bent of Jackson Pollock's work in relation to broad social trends); see also David John Frank \& John W. Meyer, The Profusion of Individual Roles and Identities in the Postwar Period, 20 SOC. THEORY 88 (2002) (discussing "dramatic rise in the cultural centrality of individual rights" during Cold War).

45. For a discussion of how these social trends influenced copyright law, see Peter Jaszi, Is There Such a Thing as a Postmodern Copyright?, 12 TUL. J. TECH. \& INTELL. PROP. 105 (2009).

46. Gibson, supra note 30, at 208.

47. Gibson, supra note 30, at 209-10; ANN EDEN GIBSON, ABSTRACT EXPRESSIONISM: OTHER POLITICS 18-19 (1997) (describing impact of post-war "age of anxiety" in response to Abstract Expressionism).

48. See de Hart Mathews, supra note 35, at 763.

49. See de Hart Mathews, supra note 35, at 776.

50. One of the most prominent controversies involved a government-funded mural project at San Francisco's Rincon Post Office Annex, unveiled in 1949. The murals, depicting the history of San Francisco, were painted in a stylized realism by Russian-born artist Anton Refregier. The artist's background and leftist activities had already made him suspect, but critics also denounced the elongated style and claimed the content disproportionately emphasized violence, racial hatred, and class struggle. In 1953, Dondero appointed a subcommittee of the Committee on Public Works to consider their removal, describing the murals as "an insult to every loyal American." de Hart Mathews, supra note 35, at $765-66$.

51. In 1949, Dondero made an oft-quoted speech:

Picasso, who is also a Dadaist, an abstractionist, or a surrealist, as unstable fancy dictates, is the hero of all the crackpots in so-called modern art .... The evidence of evil design is everywhere .... The question is, what have we, the plain American people, done to deserve this sore affliction that has been visited upon us so direly; who has brought down this curse upon us; who has let into our homeland this horde of germ-carrying art vermin? 95 CONG. REC. 11, 584-85 (1949) (statement of Rep. Dondero). Dondero was also hostile to museums, particularly the Museum of Modern Art. He singles out Paul J. Sachs, an honorary trustee, explaining that as head of the Fogg Museum, Sachs "accepted, nurtured, and exalted the whole school of so-called modern and contemporary art, but more catastrophic than that, the Fogg Museum . . . trained many of its effeminate elect to be directors of museums throughout our land." Id. at 11, 586. 
and ideals. $^{52}$

The contradiction-Stalin endorsed dramatic battlefield victories and romantic pastoral scenes, not abstraction-did not necessarily go unnoticed. ${ }^{53}$ But Dondero's arguments struck a chord with fellow conservatives and intersected with an intra-cultural battle between realism and abstraction playing out in artistic circles. ${ }^{54}$ Artists who had achieved lucrative commissions working in the realistic tradition viewed the rise of abstraction with some concern, and were not averse to assisting in Dondero's political attacks. ${ }^{55}$

Although the extent of Dondero's influence is unknown, his scaremongering prompted several protests of government-sponsored art exhibitions (often joined by traditional academic artists and illustrators), ${ }^{56}$ the first being the State Department's exhibition, Advancing American Art. ${ }^{57}$ The exhibition, slated to travel Europe and Latin America as part of a cultural exchange program, ${ }^{58}$ was ultimately cancelled upon report by the House Committee on un-American Activities that over twenty of the artists selected were "definitely New Deal in various shades of communism." 59 The exhibit was declared "as foreign to the American way as is the Moscow radio."60 Other than citing Jackson Pollock and two other Abstract Expressionists among the alleged subversives, ${ }^{61}$ however, Dondero never precipitated direct censorship of these artists. ${ }^{62}$ Censorial controversies like the

52. de Hart Mathews, supra note 35, at 772, 776; see also William Hauptman, The Suppression of Art in the McCarthy Decade, ARTFORUM, 48, 48 (Oct. 1973).

53. See Howard Devree, Modernism Under Fire: Newest Attack is Full of Contradictions, N.Y. Times, Sept. 11, 1949, at X6 (countering that "it is the sturdy individualism, the refusal of modernism to become propaganda or to cater to the anecdotal and the illustrative that have led to its suppression under totalitarian governments"); see also 95 CONG. REC. 12,099 (1949) (statement of Rep. Javits) ("The very point which distinguishes our forum of free expression from communism is the fact that modern art can live and flourish here without state authority or censorship and be accepted by Americans who think well of it.").

54. ARthur C. DAnto, After the End of ART 120 (1995) (discussing "almost theological intensity" of division between abstraction and realism); Bradford Collins, Life Magazine and the Abstract Expressionists, 1948-51: A Historiographic Study of a Late Bohemian Enterprise, 73 ART BULL. 283, 285 (1991) (discussing polarization among critics supporting abstraction versus realism); Aline B. Louchheim, The ABC (or XYZ) of Abstract Art, N.Y. TIMES, July 11, 1948, at SM16.

55. See de Hart Mathews, supra note 35, at 775-77.

56. de Hart Mathews, supra note 35.

57. See Hauptman, supra note 52, at 49 (quoting accusations that works selected for exhibition were products of "left-wing painters who are members of Red fascist organizations"); Louis Menand, Unpopular Front: American Art and the Cold War, NEW YORKER 174, 175 (Oct. 17, 2005) (book review) (discussing attack on exhibition by conservative artist organization).

58. The State Department regularly sponsored traveling exhibitions pursuant to a Cultural Cooperation Program initiated in 1938. See Hauptman, supra note 52, at 48.

59. See 93 CONG. ReC. 5,220 (1947) (statement of Rep. Busbey) (referring to the art exhibit as a "disgrace to the United States" and having "sinister aspects").

60. Id. at 5,221.

61. See 95 CONG. REC. 11,585 (1949) (statement of Rep. Dondero) (including abstract artists Jackson Pollock, Robert Motherwell, and William Baziotes as "American satellites" of other subversives).

62. Notably, the State Department exhibition from 1947 did not include Abstract Expressionist work, but other American artists experimenting with abstraction, e.g., Milton Avery, Stuart Davis, Georgia O'Keefe, etc. 
State Department's cancelled exhibition, however, offered content to the rhetoric of "freedom of expression" adopted by the art community. ${ }^{63}$

Moreover, in response to Dondero's charges that modernism constituted a vast communist conspiracy, a counteroffensive was launched. The aesthetic thesis was laid out by Alfred Barr, Director of The Museum of Modern Art, in, Is Modern Art Communistic?, a letter published in The New York Times. ${ }^{64}$ Barr argued, essentially, that political involvement led to bad art (realism), and a lack of political intervention resulted in high quality art (abstraction). "Let's look at the record in Russia and Germany," he instructed readers, contrasting photographic reproductions of bland historical paintings "admired and honored" in Soviet Russia and Nazi Germany with works by Van Gogh and Chagall, "hated and feared" under those regimes. ${ }^{65}$ Equating abstraction with communist ideology was merely a false accusation, Barr claimed, leveled by "resentful academic artists and their political mouthpieces in Congress and elsewhere."66 Politics had to be purged from art for the sake of artistic quality.

\section{B. The Apolitical Art of American Democracy}

" $[F]$ reedom of the arts is a basic freedom, one of the pillars of liberty in our land... . But, my friends, how different it is in tyranny. When artists are made the slaves and the tools of the state; when artists become the chief propagandists of a cause, progress is arrested and creation and genius are destroyed." 67

- Dwight D. Eisenhower

The counteroffensive of art as both apolitical and American was wildly successful. In the 1950s, Abstract Expressionism was recoded as an American avant-garde art movement. The artists were cast as a blend of Romantic artists and rugged, archetypically male frontiersmen; as described by one art historian, their image was "100 percent heterosexual masculinity." 68 They were rebels, innovators, and, most prominently, "action painters." 69 The robust, gestural brushstrokes of their outsized canvases came to embody "the heroic pathos of

63. See Edward Alden Jewell, Federal Convention - Shows of the Week, N.Y. TimeS, June 1, 1947, at X6 (describing symposium hosted by American Federation of Arts, "Freedom of Expression for Artists," as a vital issue in light of attacks on State Department's permanent collection and cancellation of traveling exhibitions).

64. Alfred H. Barr, Jr., Is Modern Art Communistic?, N.Y. Times, Dec. 14, 1952, at SM22.

65. Id.

66. Id

67. Statement of Dwight D. Eisenhower at the 25th Anniversary of the Museum of Modern Art (Oct. 19, 1954), http://www.moma.org/momaorg/shared/pdfs/docs/press_archives/1874/releases/ MOMA_1954_0095_89.pdf?2010[http://perma.cc/8DTJ-27ED].

68. Gibson, supra note 30, at 2.

69. The name "action painters" was coined by art critic Harold Rosenberg, who described the painter's canvas as an arena and the act of painting a transcendent, physical drama. See Harold Rosenberg, The American Action Painters, ARTNEws, Jan. 1952, at 22, 48 ("The American vanguard painter took to the white expanse of the canvas as Melville's Ishmael took to the sea."). 
existential authenticity"70 (see figures 1 and 2). The branding was reinforced by the artists' public personae of bohemian antagonism toward social conventions. ${ }^{71}$

[image reproduced in print version only]

Figure 1. Jackson Pollock, Autumn Rhythm (Number 30) (C) The Pollock-Krasner Foundation / Artists Rights Society (ARS), New York

[image reproduced in print version only]

Figure 2. Willem de Kooning, Easter Monday

(C) 2015 The Willem de Kooning Foundation / Artists Rights Society (ARS), New York

70. Gibson, supra note 30, at 30

71. See Collins, supra note 54, at 292-94 (discussing popular myth of societal antagonism and analyzing photograph accompanying story published by Life magazine in 1951, in which fifteen Abstract Expressionist artists solemnly glare at the camera with folded arms). 
The artist who captivated the attention of the popular press most was Jackson Pollock, dubbed "Jack the Dripper," for his poured paint technique ${ }^{72}$ (figure 3). Pollock, the emotionally-tortured, hard-drinking artist from Cody, Wyoming, has been described as the first American "artist-celebrity."73 He was twice profiled in Life magazine, with stories celebrating both his self-destructive personal traits and his incomprehensible, enigmatic painting. ${ }^{74}$ In 1951, Pollock's signature drip paintings served as backdrops for fashion shoots featured in Vogue. ${ }^{75}$

[image reproduced in print version only]

Figure 3. Photo @ Martha Holmes / The LIFE Picture Collection / Getty Images

Art critics - especially Greenberg — championed Abstract Expressionist painting as a uniquely American shake-up of the Western history of art. ${ }^{76}$ At the same time, Greenberg sought to overcome the "lurking provincial fate" of American $\operatorname{art}^{77}$ by emphasizing its European pedigree. ${ }^{78}$ Greenberg's art theory, formalism, was now divested of prior social goals and focused exclusively on the self-contained, physical properties of the work as an end unto itself. ${ }^{79}$ Greenberg presented his

72. See Collins, supra note 54 , at 289 .

73. See Collins, supra note 54, at 298.

74. Gibson, supra note 30, at 2; see also Collins, supra note 54, at 289-90 (discussing Pollock's media attention following Life magazine article from 1949, entitled, Jackson Pollock: Is he the greatest living painter in the United States?); cf. ANFAM, supra note 29, at 16 (calling Abstract Expressionists "the last artistic generation to internalize romantic stereotypes").

75. See Thomas Crow, Fashioning the New York School, in MODERN ART IN THE COMMON Culture 39, 39-41 (1996).

76. See, e.g., Clement GreEnBerg, AMERICAN-TyPe PAINTING (1955/1958), reprinted in ART AND CUlTURE: CRITICAL ESSAYS, supra note 38, at 209 (asserting that Abstract Expressionist works "constitute the first manifestation of American art to draw a standing protest at home as well as serious attention from Europe"); Rosenberg, supra note 69, at 23 (repeatedly referring to Abstract Expressionism as "American" painting).

77. GREENBERG, supra note 76, at 228 (observing that until now, "[t]his country had not yet made a single contribution to the mainstream of painting or sculpture").

78. See GreEnBerG, supra note 76, at 211 (championing the Abstract Expressionists while noting that "every one of them started from French art").

79. See Thomas Crow, The Practice of Art History in America, 135 DaEdalus 70, 79 (2006) 
discriminating eye as an objective account of artistic quality, discernable by the object's visual properties, alone. ${ }^{80}$ Although claiming not to favor a particular style, Greenberg persistently viewed realism as inferior, disqualifying American social realist painters like Ben Shahn from the ranks of greatness alongside Stalin's artistic henchmen. ${ }^{81}$

In Greenberg's quasi-Kantian theory of visual development, artists steadily rejected representational illusion for a purer, self-referential idiom. ${ }^{82}$ The Museum of Modern Art echoed this logic in Barr's exhibition layout: European modernism unfolded as a genealogical progression of increasingly abstract form, moving from Impressionism, to Cubism, and ultimately, to Abstract Expressionism. ${ }^{83}$ Greenberg's devotion to the purity of painting and its attendant imperative of increasing abstraction could not accommodate Cubism's contemporaries like Surrealism, which depicted the subconscious through naturalistic form and pictorial illusion (despite its interplay with Abstract Expressionist themes). Nor could it house the conceptual antics of artist Marcel Duchamp, who later configured his aesthetics in opposition to the physicality of painting. As Duchamp would explain, "I was interested in ideas - not merely in visual products." 84

Liberal intellectuals viewed Abstract Expressionism as contrary to American materialism and mass culture, and thus deeply moral and humanistic. The influential art historian Meyer Schapiro said at the time, "[p]ainting and sculptures, let us observe, are the last hand-made personal objects within our culture." ${ }^{\circ 5}$ Yet, as suggested, the Abstract Expressionists enacted mainstream values and participated in popular culture. ${ }^{86}$ Their apparent rejection of society paradoxically

("The new power of American abstract painting in the postwar period seemed to confirm criteria of value that required no justification outside the formal character of any individual work . ...").

80. See ClEMENT GREENBERG, ABSTRACT, REPRESENTATIONAL, AND So ForTH (1954), reprinted in ART AND CULTURE: CRITICAL ESSAYS, supra note 38, at 133 ("Art is a matter strictly of experience, not of principles, and what counts first and last is quality; all other things are secondary.").

81. See id. at 135 (asserting that "representational painting and sculpture have rarely achieved more than minor quality in recent years, [while] major quality gravitates more and more toward the nonrepresentational"); GREENBERG, supra note 76, at 229 ("At the Biennale in Venice in 1954, I saw how de Kooning's exhibition put to shame not only the neighboring one of Ben Shahn [a social realist painter], but that of every other painter his age or under in the other pavilions.").

82. Clement Greenberg, Modernist Painting, in ARTS YEARBOOK 4 103, 103 (Hilton Kramer ed., 1961) (identifying Kant as the source of modernism's "self-critical tendency" and pursuit of purity). Modernism, in broader terms, is associated with eighteenth-century Enlightenment philosophers "in their efforts to develop objective science, universal morality and law, and autonomous art according to their inner logic." (quoting Jürgen Habermas, Modernity-an Incomplete Project, in THE ANTIAesthetic: Essays on Postmodern Culture 3, 9 (Hal Foster ed., 1983)).

83. See Harold Rosenberg, The AnXious OBJect 232 (1964) (critiquing formalism as a public relations approach to art, reflected in "Mr. Barr's pamphlet, intellectually typical of this sort of art appreciation and scholarship, [which] educates its readers to be amateur art historians and to admire paintings and sculptures as contributions to the evolution of forms").

84. Marcel Duchamp, "Painting . . . At The Service Of The Mind" (1946), reprinted in HERSCHEL B. CHIPP, THEORIES OF MODERN ART 392, 394 (1968).

85. See Meyer Shapiro, Recent Abstract Painting (1957), reprinted in MODERN ART: 19TH AND 20TH CENTURIES 213, 217 (1979).

86. See supra notes 68-75 and accompanying text.; see also LEJA, supra note 44, at 4 ("Abstract Expressionism had much more in common with the mainstream culture than some of its aggressively 
dovetailed with prevailing cultural myths. ${ }^{87}$ Despite the apparent obstruction of audience communication, nonrepresentational art's elusive meaning was legible within a particular social structure, as intellectually challenging and "high brow," where easily-accessible realism was "middle brow," and mass culture "low brow." $" 88$

On the crest of international success, Abstract Expressionism embodied the ideals of freedom of expression in the United States. As the quotation from President Eisenhower above reflects, modernism was America's art, spawned by democracy and the ideal of individual liberty. During this period, President Eisenhower implemented a dedicated program of "cultural warfare," in which attributes of American culture were systematically disseminated in Western Europe, showcasing the fruits of capitalism against the barren landscape of communism. ${ }^{89}$ The government's self-advertised policy of non-intervention, ironically, contradicted the paradigm it purported to represent. The apolitical paintings of Abstract Expressionism became a flagship symbol of a political system. Despite efforts to abstain from official sponsorship of art exhibitions abroad, the United States was perceived by many as having an "official style," Abstract Expressionism. ${ }^{90}$

If, as some have claimed, the government was either funding or promoting a particular type of art, the gleam of contrast to Soviet nationalistic art further tarnishes. ${ }^{91}$ The refusal to censor art had itself become a political message. In

elitist defenders would allow.").

87. Gibson, supra note 30, at 30; LEJA, supra note 44, at 113-14 (suggesting that "noir-ish" presentation in media "was often more influential in the culture's absorption of the New York School artists than was their work").

88. Collins, supra note 54, at 290-91 (discussing 1949 article in Life magazine featuring illustration of three men, each looking at a picture: the intellectual elite "high-brow" stands before a Picasso painting, the "conservative and stable upper middle-brow" is presented studying a Grant Wood reproduction, and the low-brow man "enjoys calendar art") (quoting Winthrop Sergeant, High-Brow, Low-Brow, Middle-Brow, Life, Apr. 11, 1949, at 99); Paul Dimaggio, Social Structure, Institutions, AND Cultural Goods: The CASE of THE United States (1991), reprinted in The POLITICS OF CUlTURE 38, 47 (Gigi Bradford et al. eds., 2000) (explaining symbolic boundaries of postWorld War II culture as divided between fine art and mass culture).

89. Max Kozloff, American Painting During the Cold War, ARTforum, May 1973, at 43, 44 (noting that although Abstract Expressionism was not a "conscious mouthpiece" for any agency, it lent itself to treatment as "benevolent propaganda"). For general information on this "cultural battlefield," especially movies, see ANDREW J. FALK, UPSTAGING THE COLD WAR: AMERICAN DisSENT AND Cultural DiPlomacy, 1940-1960 178-211 (2010); see also Kenneth Osgood, Hearts and Minds: The Unconventional Cold War, 4 J. COLD WAR STUD. 85 (2002) (review essay); Thomas W. Braden, I'm Glad the CIA is Immoral, SATURDAY EVENING Post, May 20, 1967, at 10 (referring to Cold War as a war fought with ideas).

90. See DanTo, supra note 54, at 127. Between 1954 and 1962, the U.S. pavilion at the Venice Biennale was owned by The Museum of Modern Art, the only privately owned pavilion. At a 1954 international exhibition of modern art held in Mexico City, all 39 countries officially sponsored their respective exhibits of "avant-garde" art, with the exception of the United States, which was sponsored by The Museum of Modern Art. See Aline B. Louchheim, Cultural Diplomacy: An Art We Neglect, N.Y. TIMES, Jan. 3, 1954, at SM16 (asserting that lack of official presence reinforced view of Americans as "cultural barbarians interested only in dollars and materialism").

91. For the leading proponents of the theory that Abstract Expressionism was "promoted" by the U.S. government, see SERGE Guilbault, How NeW York StOle the IDEA OF MODERN ART (Arthur 
response to charges of communist affiliations among artists selected for a Moscowbound exhibition of art in 1959, one congressman argued, "I believe that it is the Soviet Union which has lost face by attempting political censorship of its artists. We do not want to get ourselves into that situation." 92 Nonrepresentational art dovetailed with this schema: it said nothing and told a great story about democracy.

Historically, the Abstract Expressionists were credited with overthrowing Paris and moving modernism's command center to New York. ${ }^{93}$ Clement Greenberg's formalist theory would account for that success by objectively-measurable advances in artistic quality. However, many critics have observed, with broader acknowledgment of cultural influences, that the rhetoric of individualism and freedom accompanying Abstract Expressionism paralleled that of the United States government during a period of unprecedented economic success and global power. $^{94}$

In the words of art historian Michael Leja, Abstract Expressionism achieved recognition as "the quintessential artistic embodiment of the qualities and ideals that the nation's mainstream, middle-class culture holds dearest: individual freedom, boldness, ingenuity, grand ambition, expansiveness, confidence, power." "95 Jackson Pollock's career (including his sensational death in 1956, in an automobile accident), offered "rich and convincing substantiation to some of the myths of the artist most deeply cherished [in] U.S. culture." 96

\section{POSTMODERN IDEAS, MESSAGES, AND POLITICS}

"The Modernist artist's isolation from sociopolitical practice has been framed and

Goldhammer trans., 1983); Eva Cockcroft, Abstract Expressionism, Weapon of the Cold War, ARTFORUM, June 1974, at 39. For statements that the U.S. government used covert funding mechanisms for cultural endeavors abroad, see Braden, supra note 89 (defending CIA strategy of making undercover payments to cultural organizations and tours, including the Boston Symphony Orchestra performing in Paris and even an English magazine, Encounter, "dedicated to the proposition that cultural achievement and political freedom were independent"). One organization frequently implicated in discussions about government cooperation with cultural organizations in the 1950s is The International Council of the Museum of Modern Art, where the author worked in the early 1990s.

92. 105 CONG. REC. 9814 (1959) (statement of Sen. Hart); cf. Eric A. Posner, Symbols, Signals, and Social Norms in Politics and the Law, 27 J. LEgAL STUD. 765, 788 (1998) (noting that political behavior has high symbolic content).

93. See, e.g., Kozloff, supra note 89, at 44 (noting that the United States had previously "exerted no earlier genuine leadership . . . in visual art"); ROBERT ROSENBLUM, American Painting Since the Second World War, in ON MODERN AMERICAN ART 62, 62 (1999) ("[I]t could well be contended that not since the invention of Cubism in Paris has Western painting undergone such fundamental reorientations as it has in the hands of some half-dozen Americans working recently in New York.").

94. Kozloff, supra note 89, at 44 ("The most concerted accomplishments of American art occurred during precisely the same period as the burgeoning claims of American world hegemony."); LEJA, supra note 44, at 5 (describing abstract expressionism as "a high-cultural correlate of the country's military, economic, and technological rise to preeminence in the Western Hemisphere during and after World War II").

95. LEJA, supra note 44, at 5.

96. LEJA, supra note 44, at 202. 
legitimized in such ideological concepts as aesthetic autonomy and formalism. "97

- Benjamin H.D. Buchloch

By the end of the $1960 \mathrm{~s}$, the proliferation of abstract painting and the hermetically self-referential, apolitical mandate of formalism defined the era of high modernism. ${ }^{98}$ Artists and art critics had already begun dismantling modernist tenets, ${ }^{99}$ but the hegemony of high modernism spirited a more concerted, multilayered rebellion. Because fragmentation was a prominent feature of postmodernism, this section selects from a multitude of postmodern themes, critical strategies, and artists.

On an aesthetic level, Greenberg's teleology of increasing abstraction toward "flatness" had a self-contained endpoint: the surface of the canvas as such. ${ }^{100}$ More broadly, modernism symbolized the end of the line for the entire Western project of art as representation and the demise of its authoritative logic. ${ }^{101}$ Postmodern critics like Douglas Crimp viewed museums as complicit in modernist aesthetic theory by institutionalizing a particular cultural order built upon the fetishized high art object. ${ }^{102}$

Reversing the internalized, existential crises reflected in Abstract Expressionism's indecipherable iconography, postmodern artists depicted banal objects of American consumption - things familiar to everyone. Most famously, Andy Warhol silk-screened Campbell's soup cans and replicated Brillo boxes virtually indistinguishable from those on supermarket shelves (see figure 7). Media previously associated with "low culture" entertainment, like photography, video, and performance art, competed for the primacy and intellectual stature of painting. ${ }^{103}$

Further challenging the centrality of the unique art object, conceptual art established a stronghold in the 1960s, critiquing the former's status as property. In the artistic community, Marcel Duchamp's idea-based aesthetics replaced the celebrated giants of abstract painting, like Pablo Picasso, as the key site of influence. As described by postmodern critic Benjamin Buchloh: "[b]ecause the

97. Benjamin H.D. BuChlOH, PAROdY AND APPROPRIATION IN FranCis PiCABIA, POP AND SIGMAR POLKE (1982), reprinted in APPROPRIATION: DOCUMENTS OF CONTEMPORARY ART 178 (David Evans ed., 2009).

98. See SANDLER, supra note 32, at 1 (criticizing "formalist writers on art, whose point of view came to dominate art criticism during the 1960's").

99. Artist Robert Rauschenberg, for example, responded to Willem de Kooning's behemoth status by erasing one of de Kooning's works and exhibiting it as his own, Erased de Kooning Drawing, 1953.

100. Frederic Jameson, Postmodernism and Consumer Society, in THE ANTI-AESTHETIC, supra note 82 , at 112 (discussing view of formal innovation as no longer possible, leaving only the possibility of imitating dead styles of the past).

101. Jameson, supra note 100, at 115.

102. Douglas Crimp, On the Museum's Ruins, OctOBER 41, 50 (Summer 1980) (arguing that postmodern practices challenged the museum's claims to represent art coherently).

103. See Douglas Crimp, Appropriating Appropriation, in APPROPRIATION 191 (David Evans ed., 2009) (discussing centrality of photography to postmodernism); cf. Rosalind Krauss, Video: The Aesthetics of Narcissism, OCTOBER 50 (Spring 1976) (discussing video work of Vito Acconci, Bruce Nauman, and Lynda Benglis). 
proposal inherent in Conceptual Art was to replace the object of spatial and perceptual experience by linguistic definition alone (the work as analytic proposition), it thus constituted the most consequential assault on the status of that object: its visuality, its commodity status, and its form of distribution."104

Postmodernists also challenged the formalist mantra of art for art's sake and its pretense of universal aesthetic standards, often directly engaging in current social and political issues. ${ }^{105}$ James Rosenquist incorporated wartime imagery in his " $\mathrm{F}$ 111" installation, ${ }^{106}$ while Jasper Johns embarked on his now-signature flag paintings. Hans Haacke challenged and exposed existing social systems, including an exhibit consisting of maps of Manhattan detailing the real estate holdings and illegal activities of their owners; the exhibition was cancelled by the Guggenheim Museum, New York. ${ }^{107}$

Painting continued, but it no longer possessed moral or aesthetic superiority, and no particular style or school approached the monolithic dominance of Abstract Expressionism. The latter became historicized in the canon, a point of commentary and quotation. Among notable examples, Roy Lichtenstein offered cartoon-like renditions of exalted, emotionally-charged brushstrokes that evoked de Kooning's painterly style (figure 4), and Mark Tansey created the mock-allegorical painting, "The Triumph of the New York School," 1984. ${ }^{108}$ Tansey's painting features a military surrender in which the losing army wears French military uniforms, and the victors, American World War II khakis. Clement Greenberg is the commander, flanked by Jackson Pollock and Willem de Kooning, among others, while Andre Breton, a leader of the French surrealist school, accepts defeat. The deliberately dated, illustrative style of Tansey's painting, philosopher Arthur C. Danto said, reflected the deeply pluralistic nature of art since the 1970s. ${ }^{109}$ Jackson Pollock as "action painter" (figure 3) was redone in Bosco syrup, in a photograph by artist Vik Muniz (figure 5). ${ }^{110}$

104. Benjamin Buchloh, Conceptual Art 1962-1969: From the Aesthetic of Administration to the Critique of Institutions, OCTOBER 105, 107 (Winter 1990).

105. THE ANTI-AESTHETIC, supra note 82, at XV.

106. WoOD, supra note 33, at 114-15.

107. See WoOD, supra note 33, at 119-124. In addition, "identity politics" came to the fore, with artists addressing gender, race, and multiculturalism - issues that lay dormant in 1950s culture. Deeper discussion of these important topics is beyond the scope of this Article.

108. Even Norman Rockwell offered visual commentary in The Connoisseur, 1961, the featured cover illustration for The Saturday Evening Post dated January 13, 1962. See Norman Rockwell MuSEUM, http://www.nrm.org/thinglink/text/Connoisseur.html [http://perma.cc/2D9D-DZ45] (noting that Rockwell constructed the abstract painting featured in his own painting by emulating Jackson Pollock's process).

109. See Arthur C. Danto, Flag-Waving at the Whitney, The NATION, Nov. 29, 1999, at 47 (describing the Tansey painting and observing that "from the seventies on, American art became more and more deeply pluralistic, to the point that artists were no longer constrained to work in any given style"); see also Howard N. Fox, The Right to be Wrong, in COLleCting THE NEW 15, 24 (Bruce Altshuler ed., 2005) (noting the absence of any single "school of thought" that dominates a core group of artists, like Abstract Expressionism).

110. My knowledge of this image and Michael Mandiberg's piece, infra note 118, owes to Alexandra Perloff-Giles's panel presentation, Prince v. Cariou: Towards a Jurisprudence of the Digital Age, at the 2015 Association for the Study of Law, Culture and Humanities Annual Conference. 
[image reproduced in print version only]

Figure 4. Roy Lichtenstein, Little big painting (1965), Whitney Museum of American Art (C) Estate of Roy Lichtenstein

[image reproduced in print version only]

Figure 5. Recreation of photograph of Jackson Pollock in Bosco syrup. Art $($ C Vik Muniz / Licensed by VAGA, New York, NY.

For postmodernists, authenticity and original authorship became sites of critique rather than veneration. ${ }^{111}$ Sherrie Levine, for example, re-photographed photographs by Walker Evans from an exhibition catalog and exhibited them, unchanged, as her own in 1979. Jeff Koons entered the art scene in 1989 with his "Banality" exhibit, a show featuring larger-than-life sculptures based on "kitschy" Hummel figurines. Another emergent postmodernist, Richard Prince, rephotographed advertisements (see figure 6). Today, following mainstream success, Koons and Prince continue to appropriate images, but, inevitably, with less

111. John Tehranian, Towards a Critical IP Theory: Copyright, Consecration, and Control, 2012 BYU L. REV. 1237, 1255 (2012) (noting that Dada and Surrealist artists "rejected notions of originality and authorial genius and challenged the rights of exclusion that might go with such constructs"). 
transgressive associations ${ }^{112}$ —and a spate of copyright litigation. ${ }^{113}$ Prince's recent gallery exhibition, comprised of thirty-eight Instagrams pulled from the internet, is the latest to elicit divisive reaction, ${ }^{114}$ legal action, ${ }^{115}$ and counter-appropriation. ${ }^{116}$

[image reproduced in print version only]

Figure 6. Richard Prince, Untitled (Cowboy), 1989 (Chromogenic print) The Metropolitan Museum of Art, (C) Richard Prince

Danto suggests that artists winning the "freedom to do anything" also marked the end of art, at least from a philosophical vantage. ${ }^{117}$ Today, artists have not ceased creating, often self-consciously addressing art commerce (including law), art history, and all aspects of society, politics, and culture. In the internet era, images are easily replicated, re-used, transformed, and copied, and meaning is always in flux. ${ }^{118}$ In this era of pluralism, new media, and unstable meanings, art

112. Koons is one of the biggest artist-celebrities working today. See, e.g., Jeff Koons: A Retrospective, WHITNEY MUSEUM OF AMERICAN ART, http://whitney.org/Exhibitions/JeffKoons [http://perma.cc/ZR6S-VMZK] (last visited July 9, 2015) (describing Koons as an artist who "pioneered new approaches to the readymade, tested the boundaries between advanced art and mass culture, challenged the limits of industrial fabrication, and transformed the relationship of artists to the cult of celebrity and the global market").

113. See Cariou v. Prince, 714 F.3d 694 (2d Cir. 2013); Blanch v. Koons, 467 F.3d 244 (2d Cir. 2006). For a more extensive discussion of photography's conflicted position in the context of copyright law, see Rebecca Tushnet, Worth a Thousand Words: The Images of Copyright, 125 HARV. L. REV. 684, 714-15 (2012), and for additional art historical background, see Sergio Muñoz Sarmiento \& Lauren van Haaften-Schick, Cariou v. Prince: Toward A Theory of Aesthetic-Judicial Judgments, 1 TEX. A\&M L. REV. 941 (2014).

114. See, e.g., Katie Sola, Artist Richard Prince Sells Instagram Photos That Aren't His for $\$ 90 \mathrm{~K}$, HufFINGTON POST (May 27, 2015, 8:59 PM), http://www.huffingtonpost.com/2015/05/27/richardprince-instagram_n_7452634.html [http://perma.cc/4H9E-JQ26].

115. Hrag Vartanian, Photographer Sends Cease and Desist Letters to Richard Prince and Gagosian, HYPERALLERGIC (Feb. 15, 2015), http://hyperallergic.com/183036/photographer-sendscease-and-desist-letters-to-richard-prince-and-gagosian/ [http://perma.cc/F2ZY-DK8N].

116. See Daniel McDermon, You Can Now Buy a \$90,000 Richard Prince Instagram Work or a $\$ 90$ 'Copy', N.Y. TIMES (May 27, 2015, 6:43 PM), http://artsbeat.blogs.nytimes.com/2015/05/27/youcan-now-buy-a-90000-richard-prince-instagram-work-or-a-90-copy/?ref=topics\&_r $=0 \quad$ [http://perma.cc/ 8 W6N-68EY] (discussing offer by website owner, whose images became source material in Prince's work, to sell identical copies of Prince's work for $\$ 90$ ).

117. Danto, supra note 109; see also DANTO, supra note 54, at 130 (identifying Pop as the point where art ended).

118. For one example of art reflecting its historical consciousness through reference and re-use, 
can be anything - pushing the limits of authorship or legality, ${ }^{119}$ incorporating digital culture, ${ }^{120}$ confronting social issues, ${ }^{121}$ and utilizing all mediums, ${ }^{122}$ even painting. But not everything is art. It can't be, or the category is meaningless.

\section{MODERNISM IN THE COURT: A BREAKDOWN}

In the aftermath of World War II, Abstract Expressionism and freedom of expression acquired a symbolic alliance in a particular socio-political contextparadoxically contingent upon the former's apolitical status. ${ }^{123}$ While deeply entangled with the idea of free expression, abstract art did not occasion either direct holding or explicit recognition as speech by the Supreme Court. ${ }^{124}$ That occurred in Hurley v. Irish-American Gay, Lesbian \& Bisexual Group of Boston, in 1995, when Jackson Pollock's painting was deemed "unquestionably shielded" by the First Amendment. ${ }^{125}$

Although a time gap between culture and law hardly seems remarkable, neither is it sufficient, by itself, to explain the Hurley Court's remark and its implications. If we apply Frederick Schauer's descriptive, historically-situated account of the scope of speech, ${ }^{126}$ Jackson Pollock's painting did not simply surface in First Amendment doctrine in the 1990s, with its 1950s meanings intact, but was rendered salient by contemporaneous social influences as a symbol, at a particular site of contested interests. In short, the Hurley case was itself a context and a cultural participant - in a culture that was not modernism.

This Part offers doctrinal background related to artistic expression chronologically, beginning with the modernist era described in Part I. It then unpacks the Hurley decision as a cultural intersection, whereby the iconic art of

see Michael Mandiberg's AFTERSHERRIELEVINE.COM, http://www.aftersherrielevine.com/ [http:// perma.cc/UR8F-J9UX] (last visited Aug. 4, 2015).

119. See Kyle Vanhemert, This Open Source Graffiti Drone Will Give Cops Nightmares, WIRED (Apr. 16, 2014, 6:30 AM), http://www.wired.com/2014/04/a-nightmare-for-cops-a-drone-that-paintsgraffiti/?mbid=social_twitter\#slide-id-720331 [http://perma.cc/UR8F-J9UX] (discussing graffiti artist Katsu, who has used a spray-paint-wielding drone to execute his work).

120. See supra notes 113 and 117.

121. See Julia Michalska, African-American artists respond to racial injustice in the US, ART NEWSPAPER (June 18, 2015), http://theartnewspaper.com/reports/157020/ [http://perma.cc/AP5CBM78] (discussing greater presence of works addressing race relations at international art fair Art Basel).

122. Artist Janine Antoni, for example, has created sculpture that includes a piece described as 600 lbs. of lard, gnawed by the artist. See BROOKLYN MUSEUM, http://www.brooklynmuseum.org/eascfa/ feminist_art_base/gallery/janineantoni.php?i=642 [https://perma.cc/3DPT-8LF2] (last visited July 9, 2015).

123. See supra Part I.

124. Abstract art was arguably rendered copyrightable expression at the time. See Mazer v. Stein, 347 U.S. 201, 214 (1954) (referring to copyrightable expression "by modernistic form or color"). If so, it would not be amenable to speech protection as an idea, pursuant to the "idea-expression dichotomy," a distinction reflected in the language of 17 U.S.C. $\S 102$ (b) and that remains unresolved for abstract art. See Patricia Krieg, Copyright, Free Speech, and the Visual Arts, 93 YAlE L.J. 1565, 1570-71 (1984) ("The idea-expression dichotomy proves more difficult to apply to non-representational art.").

125. 515 U.S. 557,569 (1995)

126. See supra notes $26-27$ and accompanying text. 
modernism acquired the Constitution's protective shelter in the midst of postmodern art's political maelstrom. Finally, it introduces modernism's misplaced sovereignty in contemporary First Amendment law, as a set of ossified aesthetic values employed to govern an incongruous artistic environment.

\section{A. The Artistic Expression Category: Politics to Formalism}

“Artistic expression" was realized as an official speech category in 1952, when the Supreme Court pronounced motion pictures a speech medium. ${ }^{127}$ Movies, the Court explained, "may affect public attitudes and behavior in a variety of ways, ranging from direct espousal of a political or social doctrine to the subtle shaping of thought which characterizes all artistic expression."128 This outward expansion of speech aligned with the socio-political culture of communist fears that had infiltrated the arts. ${ }^{129}$ The opinion, however, also emphasizes the film's narrative features. $^{130}$

Popular entertainment magazines had acquired speech status a few years earlier, with overt references to the politics of arts regulation. The Supreme Court, for example, found a constitutional violation in the postmaster's revocation of a postage subsidy to Esquire magazine, on grounds of poor taste. ${ }^{131}$ Justice Douglas asserted, "a requirement that literature or art conform to some norm prescribed by an official smacks of an ideology foreign to our system." 132 In Winters $v$. New York, the Court held that the First Amendment embraced violent crime stories, warranting the same constitutional protection as "the best of literature." 133 "Everyone is familiar with instances of propaganda through fiction," the Court

127. See Joseph Burstyn, Inc. v. Wilson, 343 U.S. 495, 501 (1952) (referring to motion pictures as a "significant medium for the communication of ideas"). Notably, the category was created in the uniquely disfavored context of a prior restraint on speech. See id. at 502 ("If there be capacity for evil it may be relevant in determining the permissible scope of community control, but it does not authorize substantially unbridled censorship such as we have here."); see also RANDALL P. BEZANSON, ART AND FREEDOM OF SPEECH 251 (2009) (suggesting that the disfavored prior restraint context somewhat diminishes the case's significance for "artistic expression").

128. Burstyn, 343 U.S. at 501.

129. The screening of Roberto Rossellini's film, The Miracle (the expression at stake in the Burstyn case), had been picketed by protestors carrying signs like, "Don't be a Communist—all the Communists are inside." See Marjorie Heins, The Miracle: Film Censorship and the Entanglement of Church and State, FREE EXPRESSION POLICY PROJECT, http://www.fepproject.org/commentaries/ themiracle.html\#twentythree [http://perma.cc/22ZG-CCBN].

130. Burstyn, 343 U.S. at 502 (holding that expressive value of motion pictures was not undermined by the entertainment purpose, as in fiction, or by the profit motive of distributors, just like "books, newspapers, and magazines"). The Court effectively overruled Mutual Film Corp. v. Industrial Commission of Ohio, 236 U.S. 230 (1915), a case involving silent film, stating, "[i]t is not without significance that talking pictures were first produced in 1926, eleven years after the Mutual decision." Id. at 502 n. 12 .

131. Hannegan v. Esquire, Inc., 327 U.S. 146, 148-49 (1946). The Court was not concerned about Congress instituting standards of taste, but found that the postmaster had exceeded his statutory authority. Id. at $157-58$.

132. Id. at 158 .

133. Winters v. New York, 333 U.S. 507, 510 (1948). 
stated. $^{134}$

Visual art's constitutional parentage occurred a generation later, through obscenity law. In 1973, the Supreme Court decided Miller v. California, establishing "serious" artistic value as an exception to obscene speech otherwise excluded from First Amendment protection. ${ }^{135}$ As Amy Adler has convincingly argued, the "serious" artistic expression exception reflects the art historical environment of the early 1970s, the tail end of high modernism. ${ }^{136}$ Formalism dominated the popular understanding of art, while the term "serious" invoked modernist ideals of sincerity, originality, and authenticity. ${ }^{137}$

Echoes of Clement Greenberg's formalist aesthetic theory had materialized in a predecessor obscenity case, in Justice Stewart's self-fashioned obscenity test: "I know it when I see it . . .."138 The Miller opinion channels this spirit by inviting classification of artistic value through the subject's autonomous visual qualities, ${ }^{139}$ pinning the choice as between art for art's sake or "hard-core sexual conduct for its own sake."140 According to Randall Bezanson, the Miller test "abruptly shortcircuited the interpretive process," 141 while another scholar notes its Kantian "preoccupation with the essence of challenged material."142

As discussed, formalist aesthetic theory measured quality exclusively by the self-referential, surface properties of the art object. ${ }^{143}$ Applying the obscenity test, Christine Haight Farley has observed, "forces courts to evaluate works for their artistic qualities."144 If so, lurking in the background of obscenity law is an affront to a fundamental tenet of First Amendment reasoning: excluding consideration of

134. Id. ("The line between the informing and the entertaining is too elusive for the protection of [a free press].").

135. Miller v. California, 413 U.S. 15, 23 (1973). Notably, images were still viewed as holding a second-tier status to words. See Kaplan v. California, 413 U.S. 115, 119 (1973) (stating that words have a "different and preferred place in our hierarchy of values"); Close v. Lederle, 424 F.2d 988, 990 (1st Cir. 1970) (finding precedent involving verbal communications unavailing to protect plaintiff's paintings of nudes because oral speech and text were "entitled to greater protection").

136. See Amy M. Adler, Post-Modern Art and the Death of Obscenity Law, 99 YAle L.J. 1359, 1364 (1990).

137. Id. at 1366; see also Haight Farley, supra note 19, at 848 (discussing same).

138. Jacobellis v. Ohio, 378 U.S. 184, 197 (1964) (Stewart, J., concurring).

139. Haight Farley, supra note 19, at 847 ("Any case in which a court must resolve whether an object is art or obscenity necessarily employs the aesthetic theory of formalism.").

140. Miller v. California, 413 U.S. 15, 35 (1973). In the language of Miller, political value is a separate category from artistic value. See id. at 24.

141. Randall P. Bezanson, The Quality of First Amendment Speech, 20 Hastings Comm. \& ENT. L.J. 275, 292 (1998) (arguing that the Miller test permits "all elements but the audience and the community and cultural forces working on it to be cut out of the assignment of meaning").

142. Anita Bernstein, The Representational Dialectic (With Illustrations From Obscenity, Forfeiture, and Accident Law), 87 CALIF. L. REV. 305, 323-24 (1999). In a companion case decided the same day as Miller, the Court echoes this essentialist presumption by dismissing the need for experts. See Paris Adult Theatre I v. Slaton, 413 U.S. 49, 56 (1973) (asserting that "[t]he films, obviously, are the best evidence of what they represent"). Years later, in the only case placing a museum director on trial for obscenity, an Ohio court rejected the relevance of context in assessing whether Robert Mapplethorpe's photographs were obscene under Miller, because "the pictures speak for themselves." See City of Cincinnati v. Contemporary Arts Ctr., 566 N.E.2d 214, 217 (Ohio Misc. 2d 1990).

143. See supra notes $78-81$ and accompanying text.

144. Haight Farley, supra note 19, at 831. 
artistic quality. ${ }^{145}$

Notably, nonrepresentational art appears in academic commentary in the early 1970s as well, described by Melvin Nimmer as noncognitive, yet "unquestionably within the First Amendment's scope."146 Years later, in 1990, nonrepresentational art became a benchmark of aesthetic value in a concurring opinion authored by Judge Posner, explaining the expressive value of nude dancers at the Kitty Kat Lounge in South Bend, Indiana. ${ }^{147}$ Pronouncing the show devoid of ideas, Judge Posner likened its cognitive emptiness to Titian's "Venus with a Mirror," a painting that, he stated, nonetheless "expresses," in the same manner as nonrepresentational painting:

There is pattern, design, harmony, and color in abstract painting, and these attributes evoke pleasure and other emotions in an appreciative viewer. But there is no story, no articulable idea, no verbal meaning. The notion that all art worthy of the name has a "message" is philistine, and leads to the weird conclusion that nonrepresentational art and nonprogrammatic, non-vocal music are entitled to less protection under the First Amendment than striptease dancing because the latter has a more distinct, articulable message. ${ }^{148}$

For Judge Posner, the expectation of narrative is, as Clement Greenberg would certainly have agreed, "philistine."149 At the same time, Judge Posner extinguishes Greenberg's high and low culture dichotomy by extending equal value to a striptease, as speech (the striptease appears to have greater value as a message). By funneling high modernist art theory through First Amendment egalitarianism, Judge Posner both enforces and undoes formalism's defining principles.

\section{B. Jackson Pollock's Painting as Speech, 1995}

The Supreme Court affirmatively endorsed Jackson Pollock's painting as speech

145. See Bezanson, supra note 141, at 277 ("It is axiomatic that the quality of speech-its goodness or badness from a literary, artistic, or aesthetic perspective, or its effectiveness in communicating to an audience-should bear no relationship to its protection under the First Amendment."); see also Brown v. Entm't Merchs. Ass'n, 131 S. Ct. 2729, 2737 n.4 (2011) ("Crudely violent video games, tawdry TV shows, and cheap novels and magazines are no less forms of speech than The Divine Comedy.”); United States v. Playboy Entm't Grp., Inc., 529 U.S. 803, 818 (2000) ("[E]sthetic and moral judgments about art and literature ... are for the individual to make, not for the Government to decree, even with the mandate or approval of a majority."); Cohen v. California, 403 U.S. 15, 25 (1971) ("Indeed, we think it is largely because governmental officials cannot make principled distinctions in this area that the Constitution leaves matters of taste and style so largely to the individual.").

146. Nimmer, supra note 15 , at 35 .

147. Miller v. Civil City of S. Bend, 904 F.2d 1081, 1094 (7th Cir. 1990) (Posner, J., concurring), rev'd sub nom. Barnes v. Glen Theatre, Inc., 501 U.S. 560, 566 (1991) (concluding that barroom dancing was protected expression, but "only marginally so").

148. Id.

149. See id. Posner's assertion that late Renaissance mythological painting is devoid of narrative content seems questionable, but in keeping with the modernist purview he expresses elsewhere. See Piarowski v. Ill. Cmty. Coll. Dist., 759 F.2d 625, 628 (7th Cir. 1985) (Posner, J.) (describing artist's stained glass windows as racially offensive and sexually explicit while pronouncing them "art for art's sake" and not politically-motivated). 
in $1995,{ }^{150}$ outside the legal domain of obscenity law and the high modernist era surrounding the Miller decision. ${ }^{151}$ Rather, high modernism's artistic valuesoriginality, the high vs. low cultural binary, and sincerity - were under assault by postmodern art. ${ }^{152}$ Further widening this chasm was art's "turn toward the political," sparking controversy on the frontlines of the 1990s Culture Wars. ${ }^{153}$ The Hurley case unfolded in the wake of the Corcoran Gallery of Art's decision to cancel an exhibition of Robert Mapplethorpe's homoerotic photographs, among other censorship disputes prompted by art that challenged entrenched social norms. ${ }^{154}$

Political speech may stand as the premiere target of First Amendment protection, but not when a connection to the National Endowment for the Arts (the "NEA") can be identified. Only a few years after the Hurley decision, the Court decided National Endowment for the Arts v. Finley, upholding a statutory provision enabling the NEA to consider "general standards of decency and respect for the diverse beliefs and values of the American public" as factors in awarding grants. ${ }^{155}$ The Supreme Court's enshrinement of apolitical nonrepresentational art as speech, in this context, missed the point entirely. In effect, the First Amendment's alliance with Abstract Expressionist art was indoctrinated at its point of rupture with politically charged postmodern art.

Although visual art was not the subject of the Hurley case, the cultural juxtaposition of Mapplethorpe's homoerotic photographs against nonrepresentational art by modernism's rugged, American hero, Jackson Pollock, is relevant because the Hurley case was a Culture Wars case. The Court analyzed whether the Boston St. Patrick's Day parade was private speech belonging to its sponsor, a Veterans' group; if so, the sponsor had a First Amendment right to exclude an Irish LGBT organization from participating in the march under a selfidentifying banner. ${ }^{156}$ The Court offered a litany of "symbolic speech" precedent

150. Hurley v. Irish-Am. Gay, Lesbian \& Bisexual Grp. of Bos., 515 U.S. 557, 569 (1995).

151. See supra notes $136-137$ and accompanying text.

152. Adler, supra note 136, at 1365-69.

153. See Amy Adler, What's Left?: Hate Speech, Pornography, and the Problem for Artistic Expression, 84 CALIF. L. REV. 1499, 1502 (1996) (referring to political art as "intricately bound up with the 'culture wars' of the past seven years, both responding to and provoking an escalating series of rightwing attacks on artistic expression").

154. The Mapplethorpe exhibition, "The Perfect Moment," was canceled by the Corcoran Gallery of Art in Washington D.C., before its scheduled opening in 1989 (the show had been previously exhibited in Philadelphia and Chicago without complaint). At a subsequent venue, the Contemporary Arts Center in Cincinnati, Ohio, the museum and its director, Dennis Barrie, were indicted under a state obscenity law. The trial court was instructed to apply the obscenity test established under Miller $v$. California, 413 U.S. 15 (1973), to each of the selected Mapplethorpe photographs, rather than viewing the exhibition as a whole. See City of Cincinnati v. Contemporary Arts Ctr., 566 N.E.2d 214, 215 (Ohio Misc. 2d 1990). Barrie and the museum were acquitted by an Ohio jury. See Isabel Wilkerson, Cincinnati Jury Acquits Museum in Mapplethorpe Obscenity Case, N.Y. Times, Oct. 6, 1990, at 1. The sexually explicit work of multi-media artist David Wojnarowicz, aimed at AIDS awareness, was similarly targeted in a sustained attack on NEA funding by conservative members of Congress and rightwing organizations. See, e.g., Wojnarowicz v. Am. Family Ass'n, 745 F. Supp. 130 (S.D.N.Y. 1990).

155. See Nat'l Endowment for the Arts v. Finley, 524 U.S. 569, 569 (1998).

156. See Hurley v. Irish-Am. Gay, Lesbian \& Bisexual Grp. of Bos., 515 U.S. 557, 569 (1995). 
(speech arising from nonverbal conduct, often involving the use of a symbol, like the flag), querying whether the parade's lack of a "particularized message" precluded constitutional coverage. ${ }^{157}$ It could not, the Court reasoned, lest Jackson Pollock's paintings stand unprotected. ${ }^{158}$

As Madhavi Sunder has insightfully discussed, the Hurley opinion, steeped in a romantic rhetoric of individual autonomy, enshrined a propertized view of speech. ${ }^{159}$ By recognizing the parade as the sponsor's private speech, the Court granted a right to exclude a voice of dissent from its discursive space, thereby reinforcing the cultural status quo. ${ }^{160}$ Pollock's work may not have been dispositive of the holding, ${ }^{161}$ but it was aligned with the sponsor's declared interest in protecting family values - mainstream convention dressed in the rights of artistic expression. $^{162}$

Notably, the Hurley Court's approach to assessing the expressive value of the parade departed from symbolic speech precedent, which had manifestly utilized context to divine the presence of a communicated message, e.g., flag desecration aimed at high-profile political events. ${ }^{163}$ Instead of considering social context as a

The case was approached as compelled speech. In the Court's analysis, if the parade was sufficiently expressive, it constituted private speech owned by the sponsor. And if the Irish-American Gay, Lesbian and Bisexual Group of Boston (employing the acronym "GLIB") was expressing an inconsistent message by marching under a banner identifying the group's name, the sponsor could not be compelled to publish that message. Id. at 561. The Court noted that although the Veterans' group had been "rather lenient in admitting participants" over the years, this did not forfeit speech protection. Id. at 569. The sponsor was thus found exempt from complying with a public accommodations law that prevented discrimination on the basis of sex. Id. at 570 .

157. Id. at 569 (citing W. Va. Bd. of Educ. v. Barnette, 319 U.S. 624, 632 (1943) (First Amendment shields refusal to salute flag); Nat'l Socialist Party of Am. v. Skokie, 432 U.S. 43 (1977) (marching with Nazi swastika); Tinker v. Des Moines Indep. Comm. Sch. Dist., 393 U.S. 503 (1969) (protecting wearing armbands to protest Vietnam war); Stromberg v. California, 51 S. Ct. 532 (1931) (display of Communist flag)).

158. Hurley, 515 U.S. at 569 (citing Spence v. Washington, 418 U.S. 405, 411 (1974) (reversing defendant's conviction for upside-down flag display with peace sign affixed, given defendant's intent to convey a "particularized message")).

159. Madhavi Sunder, Authorship and Autonomy as Rites of Exclusion: The Intellectual Propertization of Free Speech in Hurley v. Irish-American Gay, Lesbian and Bisexual Group of Boston, 49 STAN. L. REV. 143, 145 (1996) (discussing the "dual tendency within the First Amendment toward a formalistic, reified (or propertized) view of speech and toward a romantic view of speaker autonomy").

160. Id.

161. Cf. Tushnet, supra note 3, at 204 (asserting that if Pollock's work was not protected, the argument in Hurley about the parade's expressiveness would require reconstruction).

162. See Sunder, supra note 159, at 153-56 (critiquing the Hurley Court's formalistic application of autonomy theory); $c f$. Owen M. Fiss, Free Speech and Social Structure, 71 IOWA L. REV. 1405, 1409-10 (1986) (arguing that the Kantian idea of intrinsic value is reflected in the over-valuation of autonomy as an end goal in free speech jurisprudence).

163. In Spence v. Washington, the case which the Hurley Court was quoted as requiring a "particularized message", the Court found that the speaker's intent was communicated given the great likelihood an audience would understand the altered flag as a protest of the concurrent Cambodian incursion and Kent State killings of students. 418 U.S. 405, 409-10 (1974) (finding that "the nature of appellant's activity, combined with the factual context and environment in which it was undertaken," rendered his conduct a form of protected expression); see also Texas v. Johnson, 491 U.S. 397, 405-06 (1989) (finding speech because the "expressive, overtly political nature of [burning a flag] was both intentional and overwhelmingly apparent," performed during the Republican National Convention in 
source of meaning, ${ }^{164}$ the Hurley opinion offers a florid description of the social role of parades in nineteenth-century Philadelphia. ${ }^{165}$ Using this displaced aesthetic metric, ${ }^{166}$ Justice Souter, speaking for a unanimous Court, concludes that the "inherent expressiveness of marching to make a point" is sufficient for constitutional status. ${ }^{167}$ The would-be marchers were thus excluded from a canvas stretching over Boston's public sidewalks.

\section{Ex Post Hurley: Disorder in The MARKetPlaCe}

Following the Hurley opinion, Jackson Pollock's painting has become a legal principle, cited when courts must determine whether a given instance of expression-typically nonverbal-constitutes speech. While legal literature addressing the scope of speech often focuses on over- or under-inclusion, ${ }^{168}$ I concentrate on the doctrinal disorder arising from this narrow site of cultural misalignment. Jackson Pollock's painting operates like a broken compass, steering courts in an endless loop of anachronistic assumptions that make no sense in a postmodern landscape.

That modernism has any effect on contemporary speech boundaries is not an obvious proposition. Indeed, postmodernism's dissolution of modernism's rigid hierarchies arguably serves the First Amendment's egalitarian purposes better than the elite connotations of Jackson Pollock's paintings. Recent Supreme Court decisions are not merely welcoming of visual media, but have situated it on the highest rung of speech protection, triggering strict scrutiny of any form of government regulation. ${ }^{169}$

Any image, it seems, is speech under the absolutist rhetoric deployed in United

Dallas).

164. See Spence, 418 U.S. at 410 (reasoning that the speaker's conduct addressed "issues of great public moment" and that the same flag display "today might be interpreted as nothing more than bizarre behavior"); see also Peter Meijes Tiersma, Nonverbal Conduct and the Freedom of "Speech", 1993 WIS. L. REV. 1525, 1538 (1993) (observing that "[c]ontext was critical" to the Spence decision). But see Joseph Blocher, Nonsense and the Freedom of Speech: What Meaning Means for the First Amendment, 63 DUKE L.J. 1423, 1471-72 (2014) (describing the Spence approach as "relatively, if not entirely, acontextual"); Robert Post, Recuperating First Amendment Doctrine, 47 StAn. L. Rev. 1249, 1252 (1995) (criticizing Spence test for its abstraction and disregard of social context).

165. See Hurley v. Irish-Am. Gay, Lesbian \& Bisexual Grp. of Bos., 515 U.S. 557, 568 (1995) (describing nineteenth century parades as "public dramas of social relations" in which "performers define who can be a social actor and what subjects and ideas are available for communication and consideration") (internal citations omitted).

166. See R. George Wright, What Counts As "Speech" in the First Place?: Determining the Scope of the Free Speech Clause, 37 PEPP. L. REv. 1217, 1243 (2010) (describing the Hurley Court's "apparent backtracking" from consideration of context).

167. Hurley, 515 U.S. at 568. The Court added that this "inherent expressiveness" explained its earlier protest march cases. Id. (citing Gregory v. Chicago, 394 U.S. 111 (1969); Edwards v. South Carolina, 372 U.S. 229 (1963); Shuttlesworth v. Birmingham, 394 U.S. 147 (1969)).

168. See Wright, supra note 166, at 1242 ("But if we define speech either too narrowly or too broadly, in light of our basic reasons for protecting speech in the first place, we again risk either repression on the one hand, or dilution and trivialization on the other.").

169. See Brown v. Entm't Merchs. Ass'n, 131 S. Ct. 2729, 2738 (2011) (applying strict scrutiny to legislation restricting sale or rental of violent video games to minors). 
States $v$. Stevens, which invalidated a statute aimed at restricting the commercial trade in animal crush videos. ${ }^{170}$ Unless falling within an established categorical proscription, ${ }^{171}$ the Court states, all speech has full protection, regardless of social or artistic value. ${ }^{172}$ Other decisions have also emphasized that the romantic notion of individual authorship is dispensable; media corporations are entitled to the same rights of expressive autonomy. ${ }^{173}$ And, consistent with First Amendment tradition, original content is not required for protection. ${ }^{174}$

However, the edges of speech are blurrier than the rhetoric suggests; as Justice Scalia reminds us, "the Amendment has no application when what is restricted is not protected speech." 175 In this light, the Stevens decision becomes less boundless. The Court invalidated a statute criminalizing the commercial trade in visual and auditory "depictions of animal cruelty," 176 but its reasoning focused less on whether the dogfight videos at issue constituted speech $^{177}$ than on the repugnant proposition of designating a new class of categorically unprotected speech. ${ }^{178}$ The Court found the statute facially overbroad, meaning unconstitutional for all the speech it might include. ${ }^{179}$ Implicitly, then, images that are "not protected speech" are still subject to regulation, and the criteria for speech status remain unknown.

Further complicating the status of visual art, speech subcategories often establish the level of constitutional protection afforded. ${ }^{180}$ In particular, commercial speech, wholly unprotected in the mid-twentieth century, is now entitled to protection of a "lesser" degree than noncommercial speech. ${ }^{181}$ The question of what constitutes speech and how to categorize it thus remains vital in a

170. United States v. Stevens, 559 U.S. 460, 470 (2010).

171. See Chaplinsky v. New Hampshire, 315 U.S. 568, 571-72 (1942) (referring to "certain welldefined and narrowly limited classes of speech" that are not within the scope of the First Amendment).

172. Stevens, 559 U.S. at 470 (finding the idea of balancing the value of protecting animal cruelty videos against its societal costs "startling and dangerous"); see also Ronald K.L. Collins, Exceptional Freedom: The Roberts Court, the First Amendment, and the New Absolutism, 76 ALB. L. REV. 409, 428 (2013) (describing speech protection under Stevens as "a virtually impossible bar for the government to overcome").

173. See Citizens United v. FEC, 558 U.S. 310, 342-43 (2010); see also Jim Chen, Conduit-Based Regulation of Speech, 54 DUKE L.J. 1359, 1419 (2005) ("In media markets, speakers deviate substantially from the romantic.").

174. See N.Y. Times Co. v. Sullivan, 376 U.S. 254, 266 (1964) (finding newspaper's publication of paid advertisement was not occluded from speech protection).

175. Nevada Comm'n on Ethics v. Carrigan, 131 S. Ct. 2343, 2347 (2011); see also Wright, supra note 166, at 1218 ("One can be a free speech absolutist, certainly, only if not everything counts as speech.").

176. Stevens, 559 U.S. at $464,468$.

177. Id. at 481-82 ("We therefore need not and do not decide whether a statute limited to crush videos or other depictions of extreme animal cruelty would be constitutional.").

178. Id. at 472 .

179. Id. at 483 (Alito, J., dissenting) (arguing that the case should have been vacated and remanded for the lower court to decide whether the videos sold by the defendant were constitutionally protected).

180. Daniel A. Farber, The Categorical Approach to Protecting Speech in American Constitutional Law, 84 IND. L.J. 917, 918-19 (2009) (observing that despite proscription on content-based distinctions, "some message types are treated with reverence while others are treated as suspiciously profane").

181. Cent. Hudson Gas \& Elec. Corp. v. Pub. Serv. Comm'n, 447 U.S. 557, 562-63 (1980); see also Zauderer v. Office of Disciplinary Counsel of Supreme Court of Ohio, 471 U.S. 626, 637 (1985) (finding protection of commercial speech "less extensive than that afforded 'noncommercial speech"'). 
regime of absolutism.

There is nothing new about the challenges of speech classification at the margins, as the commercial speech doctrine has demonstrated. ${ }^{182}$ Yet artistic expression precedent is more helpful to some types of media than others. Motion pictures, as discussed, arrived with venerable Constitutional grounding: words and presumptive politics. ${ }^{183}$ This hardware resurfaces in Brown v. Entertainment Merchants Association, where the Court unqualifiedly embraces video games, noting their use of "familiar literary devices," 184 a feature that catapults video games to the ranks of The Divine Comedy. ${ }^{185}$ Justice Scalia, who authored the opinion, also imports the political presumptions of mid-century entertainment cases like Winters, side-stepping any need for judicial interpretation. ${ }^{186}$

However, such connections are scarce when the subject claims protection as visual art-already a non grata topic in judicial reasoning. First, nonverbal expression has a less fortunate lineage as speech, with the Court considerably more attentive to the need for boundaries by requiring indicia of communication. ${ }^{187}$ At the same time, art's doctrinal presence rests largely on the formalistic predicate of not being obscene, despite its inescapable associations of aesthetic quality. ${ }^{188}$ Added to this mix is the Hurley decision, instructing that nonverbal, nonrepresentational art does not require a communicated message to receive full protection. ${ }^{189}$ The sum of these premises makes for a perplexing set of "boundary criteria" to guide courts when First Amendment protection is invoked. ${ }^{190}$

182. See Zauderer, 471 U.S. at 637 (noting that although commercial speech was unquestionably within the First Amendment's ambit, "the precise bounds of the category of expression that may be termed commercial speech" were "[m]ore subject to doubt").

183. See Joseph Burstyn, Inc. v. Wilson, 343 U.S. 495, 501 (1952); see also supra notes 126-129.

184. Brown v. Entm't Merchs. Ass'n, 131 S. Ct. 2729, 2733 (referring to "characters, dialogue, plot, and music"); see also Am. Amusement Mach. Assoc. v. Kendrick, 244 F.3d 572, 579 (7th Cir. 2001) (finding video games protected speech due to "literary" nature and story lines).

185. Brown, 131 S. Ct. at 2737 n.4 ("Reading Dante is unquestionably more cultured and intellectually edifying than playing Mortal Kombat. But these cultural and intellectual differences are not constitutional ones.").

186. Id. at 2733 ("Everyone is familiar with instances of propaganda through fiction." (quoting Winters v. New York, 333 U.S. 507, 510 (1948) and explaining that asking courts to distinguish between politics and entertainment would be "dangerous to try")); see also supra notes 132-133 and accompanying text. For a discussion of distinguishing entertainment and politics in relation to the Brown decision, see R. George Wright, Judicial Line-Drawing and the Broader Culture: The Case of Politics and Entertainment, 49 SAN DIEGO L. REV. 341 (2012).

187. See Spence v. Washington, 418 U.S. 405, 409 (1974) (cautioning that "an apparently limitless variety of conduct can be labeled 'speech' whenever the person engaging in the conduct intends thereby to express an idea" (quoting United States v. O’Brien, 391 U.S. 367, 376 (1968))). A similar sentiment was later articulated with respect to recreational dancing. See City of Dallas v. Stanglin, 490 U.S. 19, 25 (1989) ("It is possible to find some kernel of expression in almost every activity a person undertakesfor example, walking down the street or meeting one's friends at a shopping mall—but such a kernel is not sufficient to bring the activity within the protection of the First Amendment.").

188. See supra notes 142-144 and accompanying text.

189. See, e.g., Comedy III Prods., Inc. v. Gary Saderup, Inc., 21 P.3d 797, 804 (Cal. 2001) (citing Hurley in noting that "the United States Supreme Court has made it clear that a work of art is protected by the First Amendment even if it conveys no discernable message").

190. See Post, supra note 164, at 1250 ("In order to determine which path of analysis a court should pursue, we must have boundary criteria for deciding when First Amendment standards shall be 
What else, courts must ascertain, belongs in a category that includes noncognitive, apolitical paintings by Jackson Pollock, but which cannot be tested by content, artistic quality, or original, individual authorship? ${ }^{191}$ The Hurley remark was rendered in a noncommercial context, yet Jackson Pollock's painting repeatedly surfaces in commercial settings; in such cases, courts must differentiate an art object (speech) from a mere object (merchandise). ${ }^{192}$ And how might a court distinguish an advertisement, receiving less extensive First Amendment protection, from a re-photographed advertisement by Richard Prince? ${ }^{193}$ In the modernist era, a broadly recognized demarcation stood between high and low culture. Postmodernism's dissolution of cultural borderlines, however, has complicated the judicial endeavor.

Two cases that rely on the Hurley Court's conclusion about Jackson Pollock's painting illustrate key features of a deep misalignment. In Kleinman v. City of San Marcos, the Fifth Circuit Court of Appeals endeavored to classify, for First Amendment purposes, a colorfully-painted, wrecked automobile used as a cactus planter, which stood outside the owner's novelty store in public view. While the owner claimed a right to artistic expression, the court disagreed, deciding that "the car-planter is a utilitarian device, an advertisement, and ultimately a 'junked vehicle""; the piece was thus subject to a state ordinance against the public display of junked vehicles. ${ }^{194}$ The court opined that the Hurley decision "refers solely to great works of art,"195 a conclusion in dubious compliance with the First Amendment's excision of quality considerations. ${ }^{196}$

In White v. City of Sparks, a Ninth Circuit court exempted an artist's sale of original paintings of nature from the city's prohibition of selling merchandise in public parks. Citing Hurley, the court rejected the city's argument that a message was required for First Amendment protection. ${ }^{197}$ Although full constitutional protection does not otherwise demand original authorship, the White court reasoned that the sale of original paintings does "more than propose a commercial

brought into play.").

191. See ETW Corp. v. Jireh Publ'g, 332 F.3d 915, 925 (6th Cir. 2003) (protecting copies of art image as speech and observing that publishers disseminating the work of others receive full First Amendment protection).

192. Unlike mere merchandise, the sale of speech is fully protected under the First Amendment. See Joseph Burstyn, Inc. v. Wilson, 343 U.S. 495, 501 (1952) ("That books, newspapers, and magazines are published and sold for profit does not prevent them from being a form of expression whose liberty is safeguarded by the First Amendment."); $c f$. Mastrovincenzo v. City of New York, 435 F.3d 78, 92 (2d Cir. 2006) (deciding whether hand-painted articles of clothing constituted art).

193. For a discussion of an example hinging on the distinction between art and advertising, see Megan Carpenter, Art and(or) Outdoor Advertising in Marfa, Texas, MADISONIAN.Net (Aug. 30, 2013), http://madisonian.net/2013/08/30/art-andor-outdoor-advertising-in-marfa-texas/ [http://perma.cc/4LSNT5CU] (discussing dispute as to whether neon-lit Playboy bunny sign outside Marfa, Texas was sculpture or advertisement).

194. Kleinman v. City of San Marcos, 597 F.3d 323, 327 (5th Cir. 2010).

195. Id. at 326 .

196. Cf. Bezanson, supra note 141, at 392 (arguing that judgments about quality tend to intervene at speech boundaries).

197. White v. City of Sparks, 500 F.3d 953, 956 (9th Cir. 2007). 
transaction."198 But the court expressly reserved judgment as to works of art "that are copies of another artist's work or paintings done in an art factory setting where the works are mass-produced by the artist or others."199

This caveat offers a striking recitation of core modernist values, whereby the inherent originality of painting still speaks loudly for constitutional purposes. Yet much postmodern art is occluded by these standards, including Andy Warhol's silkscreened prints, often produced by assistants in a studio known as the Factory (see figure 7), and sculptures by Jeff Koons, whose oeuvre is defined by copying, mass production, and, of course, copyright litigation. What would the court have said to appropriation artist par excellence Richard Prince, vending his reproductions of J.D. Salinger's original publication of The Catcher in the Rye on the perimeters of Central Park (an event staged following the district court's unfavorable copyright ruling in Cariou v. Prince) $?^{200}$ The books were identical to Salinger's first edition except for the author's name (replaced with Richard Prince) and a disclaimer stating, "This is an artwork by Richard Prince. Any similarity to a book is coincidental and not intended by the artist." At the end: "C Richard Prince." 201

[image reproduced in print version only]

Figure 7. Andy Warhol, Vegetarian Vegetable from Campbell's Soup II; @ 2015 The Andy Warhol Foundation for the Visual Arts, Inc. / Artists Rights Society (ARS), New York

\section{MODERNISM'S LENS}

That the Supreme Court's first specific reference to visual art's status as speech emerged by way of Jackson Pollock's nonlinguistic drip paintings makes sense. This was flagship artistic expression in the 1950s, triumphant alongside the First

198. Id. at 957 ("White's paintings, which communicate his vision of the sanctity of nature, do more than propose a commercial transaction and therefore are not commercial speech.").

199. Id. at 956 n.4.

200. See 784 F. Supp. 2d 337 (S.D.N.Y. 2011) (granting plaintiff's motion for summary judgment on Prince's liability for copyright infringement and finding Prince's appropriation of plaintiff's copyrighted photographs was not fair use), rev'd in part, vacated in part, Cariou v. Prince, 714 F.3d 694 (2013). I thank Rebecca Tushnet for suggesting this example.

201. For further details about this work, see Kenneth Goldsmith, Richard Prince's Latest Act of Appropriation: The Catcher in the Rye, POETRYFOUNDATION.ORG, http://www.poetryfoundation.org/ harriet/2012/04/richard-princes-latest-act-of-appropriation-the-catcher-in-the-rye/ [http://perma.cc/ 5TZG-AWDA] (last visited Sept. 4, 2015). 
Amendment's rise in cultural prominence. That we recognize the intuitive correctness of this connection even today makes sense in light of the enduring authority of twentieth-century ideas and norms in shaping First Amendment discourse. What makes less sense is the implicit assumption that a bare reference to the artifactual residue of this symbolic construct, as reified in the Hurley opinion, provides a meaningful lens for considering art as constitutional speech today. Nonrepresentational art in contemporary First Amendment law, I argue, is a discursive trompe l'oeil. It appears as an expansive embrace of artistic expression, yet works from cramped conceptual quarters, with no view.

\section{A. TheOry: Apolitical Things AND AUtonomy}

The Hurley Court did not so much embrace Jackson Pollock's paintings as speech, as deploy the cultural certainty of that conclusion. It did so in a particular way, summoning the "painting of Jackson Pollock," outside of historical context or, for that matter, any particular act of display or expression. ${ }^{202}$ Unmoored from the social context that animated its First Amendment salience, Jackson Pollock's work was formally declared speech as canonized, high-value art. ${ }^{203}$ Not only was there no threat of censorship, but also no grounding in the most fundamental theories undergirding the scope of speech: politics and ideas. ${ }^{204}$

Nonrepresentational art's speech status, however, remains a surprising staple of normative legal theory. Robert Post avers that apolitical, noncognitive artworks "comfortably fit" his concept of democratic participation through public discourse. $^{205}$ On the other hand, James Weinstein, also advancing a theory of participatory democracy, finds its "greatest explanatory shortcoming" in the Court's robust protection of "non-ideational art."206 Weinstein considers, but ultimately resists, the proposition that abstract art merits First Amendment protection as a form of political dissent, evidenced by suppression under totalitarian regimes. $^{207} \mathrm{He}$ thus recognizes its "rigorous protection" but cannot accept a

202. Cf. Newton v. LePage, 700 F.3d 595, 601 (1st Cir. 2012) (asserting that "[w]hile the mural is itself not speech, the First Amendment protects artistic as well as political expression").

203. See Rubenfeld, supra note 17, at 35 (noting that the Hurley Court named "great artists," whose work made sense as protected speech precisely because it was "unquestionably great and hence of great value").

204. Schauer, supra note 17, at 1306 ("We are required to accept the view that the Constitution gives speech and press special protection, that in close cases we must develop an underlying theory of the first amendment, and that this underlying theory must be consistent with, and preferably supportive of, the special protection for speech given by the document.").

205. See Post, supra note 12, at 486 ("Art and other forms of noncognitive, nonpolitical speech fit comfortably within the scope of public discourse."). Among the skeptical commentary, see Tushnet, supra note 3, at 207 (referring to Post's theory as a "weakly sociologized account of art's coverage").

206. Weinstein, supra note 6, at 499 n.45 (finding protection of "non-ideational" art incompatible with theory of participatory democracy).

207. Id. For proponents of this theory, see Eberle, supra note 5 (illustrating art's subversive power in "regimes like Nazi Germany and Soviet Russia that considered art to have the potential to be deeply threatening to the social order"); Marci A. Hamilton, Art Speech, 49 VAND. L. REV. 73 , 101 (1996) (discussing Hitler and Stalin as evidencing the importance of protecting art as free speech). For a similar justification tied to Senator Dondero, see Nahmod, supra note 5, at 256 (asserting that Senator 
political justification, leaving nonrepresentational art as the solitary thorn in the side of his speech principle. ${ }^{208}$

The confluence of nonrepresentational art and speech is obvious from the vantage of autonomy or self-realization as speech principle, another branch of Abstract Expressionism's auspicious alliance with freedom of expression. ${ }^{209}$ Yet autonomy proponents likewise insist on abstract art's apolitical, ahistorical status, shoring up its speech status in the romantic author paradigm. ${ }^{210}$ C. Edwin Baker argues that, "[t]hough artists might aim to influence public opinion about aesthetics, many probably want simply to produce good art - that is, the [Hurley] Court most likely sees itself as protecting exercises of expressive autonomy." 211 The Court perhaps sees itself this way, but to accept this justification at face value overlooks the historical context in which the decision was rendered: Jackson Pollock was forty years dead and his works widely revered as art objects. Any expansion of the scope of speech wrought by the Hurley decision offered little to postmodern artists embroiled in the Finley case, for example, where the Court upheld government control over matters of taste in arts funding.

\section{B. Context: The Museum Confines}

"All museums. . are museums of modern art, to the extent that the judgment of what is art is based on an aesthetic of formalism." 212 -Arthur C. Danto

Mark Tushnet has identified the many anomalies in legal reasoning induced by the First Amendment's coverage of art, deliberately avoiding aesthetic theory. ${ }^{213}$ But modernist theory is not so easily extracted, as when Tushnet asserts that nonrepresentational art "exists for its own sake..., which is why governments rarely try to regulate it." 214 What Tushnet makes explicit in his analysis is embedded in most legal commentary: a circumscribed universe of "serious and

Dondero "was correct in understanding that nonrepresentational art can and does have considerable influence on society's ideas and behavior").

208. See Weinstein, supra note 6, at 499 n.45 (acknowledging arguments that abstract art constitutes a form of political dissent and concluding, "[s]till, I am not sure that these arguments adequately explain the rigorous protection afforded non-ideational art").

209. See Blake, supra note 6, at 1082 (defending inclusion of nondiscursive visual art on grounds that self-development, "either through making or receiving expression, is actually an end in itself"); Blocher, supra note 164, at 1452 (asserting that even nonsensical or noncognitive artistic expression is important to "the autonomy and self-development of those speaking it");

210. Baker, supra note 16, at 271 ("Abstract art and compositional music, found, for example, in the Court's dicta referring to Jackson Pollock and Arnold Schoenberg's music, require a stretch to justify as political speech or truth propositions to test in a marketplace of ideas."); Seana Valentine Shiffrin, Methodology in Free Speech Theory, 97 VA. L. REV. 549, 555 (2011) (asserting that neither Post's nor Weinstein's theory of public discourse offers direct support for protecting abstract art).

211. C. Edwin Baker, Is Democracy a Sound Basis for a Free Speech Principle?, 97 VA. L. REV. 515,528 (2011).

212. DANTO, supra note 54, at 111.

213. Tushnet, supra note 3 , at 170 n.5.

214. Tushnet, supra note 3, at 203. But see Blocher, supra note 164, at 1425-26 (asserting that the Hurley Court "reassuringly declared" Pollock's work to be covered speech and suggesting other artists and speakers of "nonsense" may have reason for concern). 
indeed important works" from the twentieth century. ${ }^{215}$ These canonized boundaries - conjuring the treasures of modern museums-quell the impetus for government censorship because they presuppose consensus-driven cultural value derived from isolated art objects. Paradoxically, and particularly with respect to nonrepresentational art, attaining that high art classification both reduces its meaning (except as an aesthetic object) and simultaneously justifies speech status. $^{216}$

Commentators who have urged context-driven means of identifying nonverbal art as speech have looked no further than traditional institutional exhibition spaces, i.e., that which is already implied in current discourse. Joseph Blocher proposes that artistic "nonsense" can be recognized as constitutional speech when it is used as art (meaning that it hangs in museums and galleries). ${ }^{217}$ Blocher's approach builds on that of Robert Post, who would recognize art through "social conventions that create constitutionally meaningful relationships," like an art exhibition. Post selects Marcel Duchamp's "readymade" sculpture, "The Fountain" (a urinal), as his example, which, Post explains, became a constitutionally cognizable idea when submitted to the social "medium of an art exhibition" in $1917 . .^{218}$

The approaches of Post and Blocher persuasively appeal to a philosophy by which we recognize "art" by the institutions comprising the art world. Notably, as Arthur C. Danto observes in the quote above, the museum as an institution is a modernist idea. ${ }^{219}$ Although postmodern art likewise circulates within the art world, its aesthetics speak to issues outside the museum. ${ }^{220}$ In this light, it bears note that Post's illustration replaces certain social conventions from 1917 with those of today to make its point. Duchamp's idea was born in a provocative taunt to institutionalized social conventions, from outside their space. Although this act stands as a quintessential moment in the history of conceptual art, its speech status, by Post's methodology, awaits reification in the "Fountain" replicas invited into museums years later-the original was discarded. In effect, the museumsanctioned physical object (modernism's key site of meaning), retrospectively creates the constitutionally cognizable idea, rather than the artist's expressive act. $^{221}$

215. See Tushnet, supra note 3, at 170 n.7 (limiting analysis to examples that are "by consensus regarded as serious and indeed important works of late Twentieth Century art").

216. See Blocher, supra note 164, at 1434 (asserting that Pollock's work lacks meaning, "despite its undoubted value and First Amendment protection").

217. Blocher, supra note 164, at 1452.

218. Post, supra note 164, at 1254.

219. DANTO, supra note 54, at 111; see also Douglas Crimp, Pictures, OCTOBER 75, 88 (Spring 1979) (noting that "the era of modernism coincides with the era of the museum").

220. Crimp, supra note 219.

221. Mark Tushnet describes Post's theory as presuming art will always be identified for constitutional purposes by "a well-informed and reasonably well-educated and sophisticated group of people who reflect on the nation's commitment to free expression," rather than average citizens. Tushnet, supra note 3, at 207. I suggest Post's theory leans more heavily on the high art category, conflating cultural value with speech value, as echoed in legal literature that ascribes equivalence between abstract art and overtly political art. See Marc Jonathan Blitz, A First Amendment for Second Life: What Virtual Worlds Mean for the Law of Video Games, 11 VAND. J. ENT. \& TECH. L. 779, 786 
Museums and galleries are reliable contexts for identifying what society recognizes as "art," at least in the Western tradition, and these institutions should possess the freedom to exhibit art of their choosing. But as free speech jurisprudence in a postmodern world, institutional environs have limited utility.

\section{UPDATE: WHAT MODERniSM DOESN'T SEE}

The First Amendment affinities that Jackson Pollock's paintings once reflected have become blinders in the postmodern era.

By assuming modernism's insistence on originality, individual genius, and art for art's sake, free speech law cannot comprehend the many iterations of postmodern art that challenge and subvert this hierarchy. How postmodern art fits into existing First Amendment principles remains unresolved, even symbolically. Consider the noble adages permeating the Hurley opinion, in which "a speaker has the autonomy to choose the content of his own message," whereas the state may sometimes prescribe "what shall be orthodox in commercial advertising."222 That distinction doesn't easily harmonize with Andy Warhol's Campbell's soup cans (figure 7) or the former commercial artist's claims that "everybody should be a machine," 223 and "somebody should be able to do all my paintings for me," a prospect realized in his techniques. ${ }^{224}$ Warhol's detached, crisp, commercial imagery lacks the moral high ground of Pollock's emotionally-turbulent drip paintings, rendering his soup cans ill-matched to the Court's romantic rhetoric of self-expression.

Further, by training its eye exclusively on modernism's unique, decontextualized object, law cannot see how postmodern means of distribution have altered its supremacy. Jack Balkin contends that the entire field of First Amendment law has been upended by digital technology, requiring systemic overhaul to meet its democratic purposes. ${ }^{225}$ The circuitry of the art world is no less dependent on and affected by digital technology, raising issues unknown to the

(2009) ("No one would question that Kasimir Malevich's famous painting White on White would be just as much a protected form of expression under the First Amendment as Francisco de Goya's realistic depictions of bullfights."); Jeffrie G. Murphy, Freedom of Expression and the Arts, 29 ARIZ. ST. L.J. 549,555 (1997) ("Would we want a theory of free expression that would protect Picasso's 'Guernica' or Soviet Realism but not Abstract Expressionism or Bach fugues? I suspect not.").

222. Hurley v. Irish-Am. Gay, Lesbian \& Bisexual Grp. of Boston, 515 U.S. 557, 573 (1995) (quoting Zauderer v. Office of Disciplinary Counsel of Supreme Court of Ohio, 471 U.S. 626, 651 (1985)).

223. Andy Warhol, quoted in G.R. SWENSON, WHAT IS POP ART? (1963), reprinted in AMERICAN ARTISTS ON ART 79, 86 (Ellen H. Johnson ed., 1982).

224. Id. at 87. Warhol claimed that commercial art was more emotional. Id.

225. See Jack Balkin, The Future of Free Expression in a Digital Age, 36 PEPP. L. REV. 427 (2009) (arguing that free speech has become less about traditional constitutional doctrine than technological design, legislative and administrative regulations, business models, and participation of end-users); Jack Balkin, Digital Speech and Democratic Culture: A Theory of Freedom of Expression for the Information Society, 79 N.Y.U. L. REV. 1 (2004) (proposing comprehensive rethinking of First Amendment rights, including issues of digital access and creative innovation through enhanced ability to copy, modify, annotate, and reconfigure expression). 
modernist era. ${ }^{226}$ As speech continues to become more propertized and driven by commercial interests, ${ }^{227}$ its intersection with intellectual property law has become more contested, introducing potential conflicts for artistic expression via copyright law that an isolated nonrepresentational painting cannot register. ${ }^{228}$

In short, the conceptual dichotomies embedded in the discourse of visual art as speech track modernism: pure expression vs. idea; individual authorship vs. mass production; noncommercial vs. commercial; high art vs. low culture. Through this anachronistic paradigm, law can barely recognize, much less address, inconsistences and potential incursions into postmodern artistic freedom like those articulated in recent scholarship on the doctrines of fair $\mathrm{use}^{229}$ and the right of publicity. ${ }^{230}$ Accounting for postmodern practices in free speech law does not deny the continuing relevance of aesthetics, abstraction, museums, or art objects - much postmodern art participates in and relies on traditional art world institutions, commerce, and values. But it does require acknowledging the limitations of modernism's lens. Rather than valorizing nonrepresentational art as the apex of free artistic expression, the law should begin questioning whether Jackson Pollock's painting, pared down to a noncognitive apolitical, timeless artifact, should remain the First Amendment's lodestar.

\section{CONCLUSION}

In Hurley v. Irish-American Gay, Lesbian \& Bisexual Group of Boston, the Supreme Court stated that Jackson Pollock's paintings are "unquestionably shielded" by the First Amendment. ${ }^{231}$ Legal commentary seized on that remark as a milestone for visual art and an expansive embrace of noncognitive, apolitical painting. This Article explains the intuited constitutional salience of nonrepresentational art in relation to the unique art historical, political, and cultural conditions of the United States following World War II.

Yet doctrinal recognition of Jackson Pollock's work as speech occurred later, in and as a cultural disconnect. Through the Hurley opinion, Pollock's apolitical painting was consecrated as speech in 1995, just as socially-charged postmodern

226. Art institutions, for example, joined the campaign urging net neutrality regulation. See National Arts and Cultural Organizations, Comment on Promoting and Protecting the Open Internet, 4 (July 15, 2014), http://apps.fcc.gov/ecfs/comment/view?id=6017896665 ("The emergence of a tiered Internet would deprive individual artists and arts organizations of the ability to benefit from online innovations while frustrating the growth of the legitimate digital marketplace.").

227. See Julie E. Cohen, The Zombie First Amendment, 56 WM. \& MARY L. Rev. 1119 (2015) (arguing that the nexus of copyright and free speech jurisprudence has been realigned as market-oriented rather than aimed at political debate).

228. See Neil Weinstock Netanel, New Media in Old Bottles? Barron's Contextual First Amendment and Copyright in the Digital Age, 76 GEO. WASH. L. REV. 952 (2008) (arguing for contextual approach to First Amendment law in relation to copyright, particularly regarding mass media access and competition from emergent platforms).

229. See Adler, supra note 22.

230. See Rebecca Tushnet, A Mask that Eats into the Face: Images and the Right of Publicity, 38 COLUM. J.L. \& ARTS 157 (2015)

231. Hurley v. Irish-Am. Gay, Lesbian \& Bisexual Grp. of Boston, 515 U.S. 557, 569 (1995). 
images sparked a vast censorial impulse. Pollock's romanticized, heroic brand of originality and genius offered a symbolic gloss to the Court's romantic rhetoric of individual autonomy, while in the background, replication, appropriation, and social dissent had become prevalent artistic strategies that directly challenged those tropes. The scope of the free speech clause opened wide enough to embrace a dead author's paintings with no discernable message as postmodern artists saw their expressive freedom contract due to inappropriate content.

The response of courts and commentators to Pollock's position as speech extends this disconnect into the new millennium, embracing an intuitively correct conclusion while neglecting postmodern artistic practices and theory that have redefined art in the past half-century. A painting by Jackson Pollock neither reflects nor speaks to these changes. As an artifactual remnant of a contingent symbolic relationship, the decontextualized drip painting makes an impoverished free speech principle. By revealing modernism's historical foundation and implicit limitations as a postmodern framework, this Article offers a step toward realigning First Amendment law with contemporary artistic expression. 